Prepared in cooperation with the Town of Barnstable

\title{
Simulated Water-Table and Pond-Level Responses to Proposed Public Water-Supply Withdrawals in the Hyannis Ponds Wildlife Management Area, Barnstable, Massachusetts
}

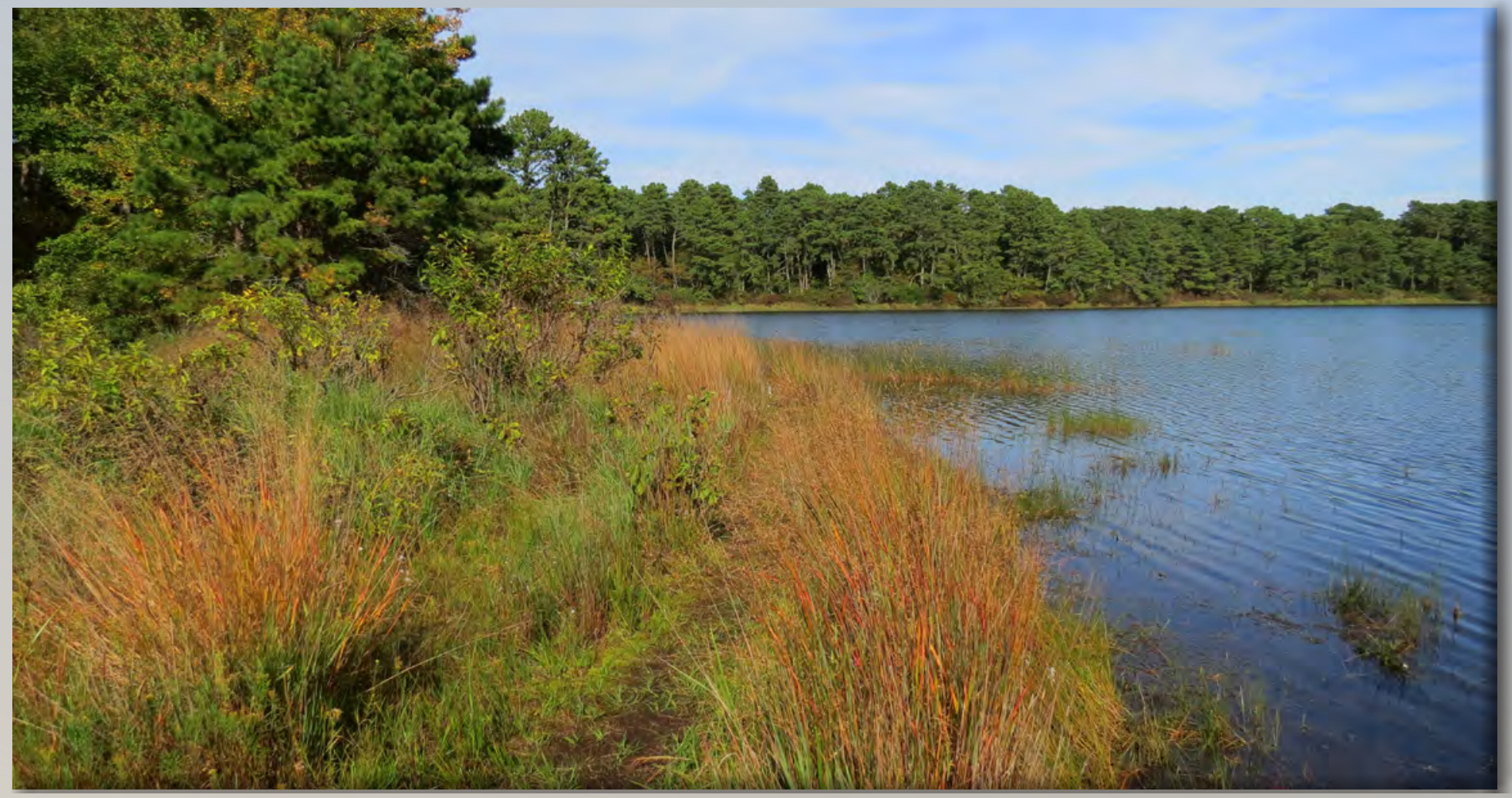

Scientific Investigations Report 2019-5121 
Cover. Shoreline of Mary Dunn Pond near the Hyannis Ponds Wildlife Management Area, Cape Cod, Massachusetts, on October 3, 2013. Photograph by David Armstrong, U.S. Geological Survey. 


\section{Simulated Water-Table and Pond-Level Responses to Proposed Public Water- Supply Withdrawals in the Hyannis Ponds Wildlife Management Area, Barnstable, Massachusetts}

By Denis R. LeBlanc, Timothy D. McCobb, and Jeffrey R. Barbaro

Prepared in cooperation with the Town of Barnstable

Scientific Investigations Report 2019-5121 


\title{
U.S. Department of the Interior DAVID BERNHARDT, Secretary
}

\author{
U.S. Geological Survey \\ James F. Reilly II, Director
}

\section{U.S. Geological Survey, Reston, Virginia: 2019}

For more information on the USGS - the Federal source for science about the Earth, its natural and living resources, natural hazards, and the environment-visit https://www.usgs.gov or call 1-888-ASK-USGS.

For an overview of USGS information products, including maps, imagery, and publications, visit https://store.usgs.gov.

Any use of trade, firm, or product names is for descriptive purposes only and does not imply endorsement by the U.S. Government.

Although this information product, for the most part, is in the public domain, it also may contain copyrighted materials as noted in the text. Permission to reproduce copyrighted items must be secured from the copyright owner.

Suggested citation:

LeBlanc, D.R., McCobb, T.D., and Barbaro, J.R., 2019, Simulated water-table and pond-level responses to proposed public water-supply withdrawals in the Hyannis Ponds Wildlife Management Area, Barnstable, Massachusetts: U.S. Geological Survey Scientific Investigations Report 2019-5121, 32 p., https://doi.org/10.3133/sir20195121.

Associated data for this publication:

McCobb, T.D., and Walter, D.A., 2019, MODFLOW2005 groundwater-flow model used to simulate water-supply pumping scenarios near the Hyannis Ponds Wildlife Management Area, Barnstable, Massachusetts: U.S. Geological Survey data release, https://doi.org/10.5066/P9U5AKLC.

ISSN 2328-0328 (online) 


\section{Acknowledgments}

The authors thank Hans Keijser, Daniel Santos, and Mark Ells of the Town of Barnstable, Massachusetts; Thomas Cambareri of the Cape Cod Commission; Richard McHorney of the Marine Biological Laboratory in Woods Hole, Massachusetts; and Jason Zimmer of the Massachusetts Division of Fisheries and Wildlife for their assistance during this study. 



\section{Contents}

Acknowledgments ……...................................................................................................................

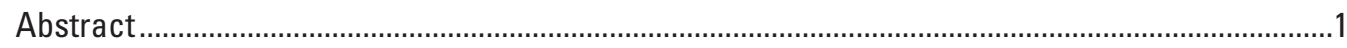

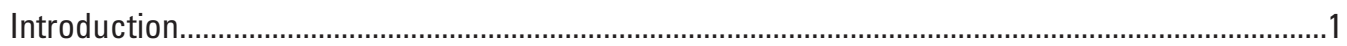

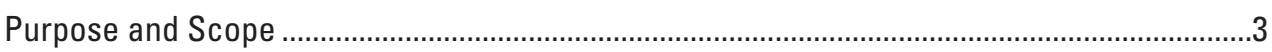

Geographic and Hydrologic Setting .............................................................................

Pumping and Wastewater Return-Flow Scenarios..................................................................

Groundwater Model and Simulation Approach................................................................................

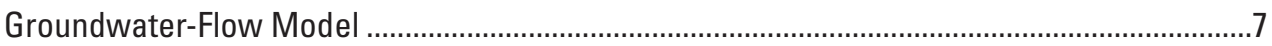

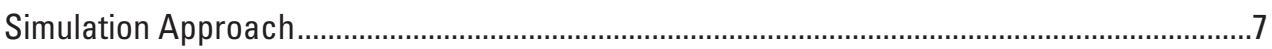

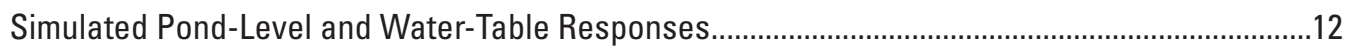

Pond-Level Responses to Production-Well Locations ............................................................12

Water-Table Response to Pumping and Wastewater Return-Flow Scenarios ........................12

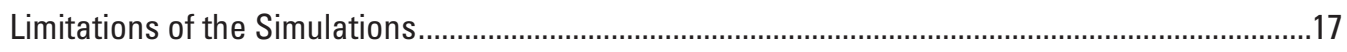

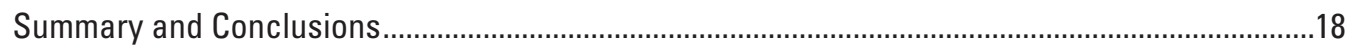

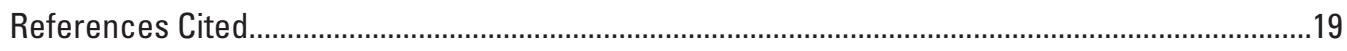

Appendix 1. Modifications to the Groundwater-Flow Model and Results of the Model

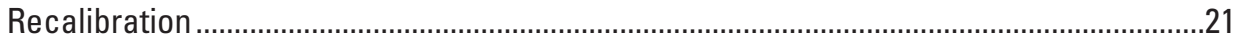

\section{Figures}

1. Map showing the Hyannis Ponds Wildlife Management Area, the simulated water-table altitudes, and U.S. Geological Survey monitoring well MA-A1W 230 on the eastern part of the Sagamore flow lens, western Cape Cod, Massachusetts............2

2. Map showing the ponds of interest in and near the Hyannis Ponds Wildlife Management Area, Barnstable, Massachusetts ............................................................

3. Map showing existing and proposed drinking-water supply wells and the Barnstable Water Pollution Control Facility in and near the Hyannis Ponds Wildlife Management Area, Barnstable, Massachusetts.

4. Map showing the model grid, model cells explicitly representing selected ponds near the Hyannis Ponds Wildlife Management Area, extent of fine-grained sediment simulated in model runs FGS20 and FGS01, and the location of the representative model-grid cell for which model layers are shown in table $3 .$.

5. Maps showing simulated water-level responses at $A$, Israel Pond, $B$, Mary Dunn Pond, $C$, Lamson Pond, $D$, Campground Pond, $E$, Little Israel Ponds, and $F$, the Northern Pondlets for pumping 100 gallons per minute from a well screened in model layer 3, Barnstable, Massachusetts.

6. Map showing the simulated composite water-level responses for Mary Dunn, Israel, and Lamson Ponds near Barnstable, Massachusetts, for pumping 100 gallons per minute from a well screened in model layer 3 .

7. Map showing simulated water-table altitudes for the 2015 reference condition and scenario 4, Barnstable, Massachusetts

8. Map showing water-table drawdown and mounding for pumping and wastewater return flow calculated as the difference in simulated water levels between the 2015 reference condition and scenario 4, Barnstable, Massachusetts. 


\section{Tables}

1. Proposed scenarios for increases in future withdrawals by the Hyannis Water System (HWS) for drinking-water supplies and associated wastewater return flows to the Barnstable Water Pollution Control Facility and distributed septic systems in the HWS service area, Barnstable, Massachusetts ...

2. Simulated locations and altitudes of screened intervals for the two proposed water-supply wells in the Hyannis Ponds Wildlife Management Area, Barnstable, Massachusetts.

3. Top and bottom altitudes and horizontal hydraulic conductivities of the layers in the modified groundwater-flow model for a representative model cell in the Hyannis Ponds Wildlife Management Area, Barnstable, Massachusetts.

4. Simulated water-table changes relative to the 2015 reference condition at selected ponds in and near the Hyannis Ponds Wildlife Management Area, Barnstable, Massachusetts, for the pumping and wastewater return-flow scenarios described in table 1 


\section{Conversion Factors}

U.S. customary units to International System of Units

\begin{tabular}{|c|c|c|}
\hline Multiply & By & To obtain \\
\hline \multicolumn{3}{|c|}{ Length } \\
\hline foot $(\mathrm{ft})$ & 0.3048 & meter $(\mathrm{m})$ \\
\hline mile (mi) & 1.609 & kilometer $(\mathrm{km})$ \\
\hline \multicolumn{3}{|c|}{ Area } \\
\hline acre & 0.4047 & hectare (ha) \\
\hline square mile $\left(\mathrm{mi}^{2}\right)$ & 2.590 & square kilometer $\left(\mathrm{km}^{2}\right)$ \\
\hline \multicolumn{3}{|c|}{ Volume } \\
\hline gallon (gal) & 3.785 & liter (L) \\
\hline \multicolumn{3}{|c|}{ Flow rate } \\
\hline cubic foot per second $\left(\mathrm{ft}^{3} / \mathrm{s}\right)$ & 28.32 & liter per second $(\mathrm{L} / \mathrm{s})$ \\
\hline gallon per minute (gal/min) & 0.06309 & liter per second $(\mathrm{L} / \mathrm{s})$ \\
\hline gallon per day (gal/d) & 0.003785 & cubic meter per day $\left(\mathrm{m}^{3} / \mathrm{d}\right)$ \\
\hline million gallons per day (Mgal/d) & 0.04381 & cubic meter per second $\left(\mathrm{m}^{3} / \mathrm{s}\right)$ \\
\hline inch per year (in/yr) & 25.4 & millimeter per year (mm/yr) \\
\hline \multicolumn{3}{|c|}{ Hydraulic conductivity } \\
\hline foot per day (ft/d) & 0.3048 & meter per day $(\mathrm{m} / \mathrm{d})$ \\
\hline
\end{tabular}

\section{Datum}

Vertical coordinate information is referenced to the National Geodetic Vertical Datum of 1929 (NGVD 29).

Horizontal coordinate information is referenced to the North American Datum of 1927 (NAD 27) or the North American Datum of 1983 (NAD 83).

Altitude, as used in this report, refers to distance above the vertical datum.

\section{Abbreviations}

$\begin{array}{ll}\text { BFD } & \text { Barnstable Fire District } \\ \text { HPWMA } & \text { Hyannis Ponds Wildlife Management Area } \\ \text { HWS } & \text { Hyannis Water System } \\ \text { MassDEP } & \text { Massachusetts Department of Environmental Protection } \\ \text { MassWildlife } & \text { Massachusetts Division of Fisheries and Wildlife } \\ \text { SWB } & \text { Soil Water Balance } \\ \text { USGS } & \text { U.S. Geological Survey } \\ \text { WPCF } & \text { Water Pollution Control Facility }\end{array}$





\title{
Simulated Water-Table and Pond-Level Responses to Proposed Public Water-Supply Withdrawals in the Hyannis Ponds Wildlife Management Area, Barnstable, Massachusetts
}

\author{
By Denis R. LeBlanc, Timothy D. McCobb, and Jeffrey R. Barbaro
}

\section{Abstract}

The glacial kettle ponds in the Hyannis Ponds Wildlife Management Area in Barnstable, Massachusetts, support a community of rare and endangered plants. The ponds are hydraulically connected to the unconfined aquifer that underlies Cape Cod. The plants are adapted to the rise and fall of water levels in the ponds as the water table fluctuates in response to seasonal and year-to-year natural changes in recharge. Pumping from wells for public water supply and recharge of wastewater at water pollution control facilities and septic systems also affect groundwater levels. The Hyannis Water System has proposed to install two additional wells in the Hyannis Ponds Wildlife Management Area and adjust rates of withdrawals and recharge of wastewater return flows for the municipal system that serves the village of Hyannis in the town of Barnstable. The proposal has raised concerns that pumping from the proposed wells could cause long-term average changes in pond levels that could adversely affect the critical pond-shore plant habitat.

An available three-dimensional steady-state groundwaterflow model was used to simulate the hydrologic effects of nine pumping and wastewater return-flow scenarios prepared by the Hyannis Water System. These effects were quantified by comparison of water levels simulated for the scenarios to water levels simulated for a reference condition based on 2015 withdrawal and wastewater return-flow rates. Maps of water-level responses were prepared to show the effects of pumping from a single well at different locations in the Hyannis Ponds Wildlife Management Area on the water levels of six ponds. Steady-state simulations of the nine scenarios indicated that the shapes of the simulated water-table contours near the wildlife management area changed only slightly at the regional scale, with the largest shifts near the wildlife management area and the Barnstable Water Pollution Control Facility. The simulated changes in pond levels at 10 ponds of interest for the nine scenarios relative to the simulated pond levels for the 2015 reference condition ranged from small increases (less than 0.1 foot) in one pond each in two scenarios to declines (drawdowns) of 1.03-1.11 feet at three ponds in one scenario. Water levels at the Barnstable Water Pollution Control Facility increased because part of the increase in total withdrawals from the Hyannis Water System wells was recharged as wastewater at the water pollution control facility.

\section{Introduction}

More than a dozen shallow glacial kettle ponds in the eastern part of the town of Barnstable on Cape Cod, Massachusetts, support a community of locally and globally rare plants (McHorney and Neill, 2007). Many of the ponds are in or near the Hyannis Ponds Wildlife Management Area (HPWMA) near the village of Hyannis in eastern Barnstable (fig. 1). The ponds are hydraulically connected to the unconfined water-table aquifer that underlies Cape Cod, and pond levels rise and fall as the water table fluctuates in response to seasonal and long-term variations in natural recharge from precipitation. Because the ponds are shallow, the fluctuations regularly expose and flood the shoreline. The community of rare plants found here has adapted to the shifting shorelines of the ponds during wet and dry periods, whereas other species such as pitch pine and oak cannot colonize the regularly inundated shoreline areas.

Pumping from the aquifer for drinking-water supply and recharge of the aquifer by land disposal of wastewater return flow also affect groundwater levels (LeBlanc and others, 1986; Walter and Whealan, 2005). Pumping near the ponds in the past has lowered the water table, reduced the size of several ponds, and exposed large areas of normally inundated pond extents (McHorney, 1997; McHorney and Neill, 2007). The Hyannis Water System (HWS), operated by the Town of Barnstable Water Supply Division, withdraws water for drinkingwater supply from several well fields in the Sagamore flow lens of the Cape Cod aquifer (Walter and Whealan, 2005; Walter and others, 2016), including wells near the HPWMA. The HWS has proposed to install two additional wells in the HPWMA to augment supplies and provide more operational 


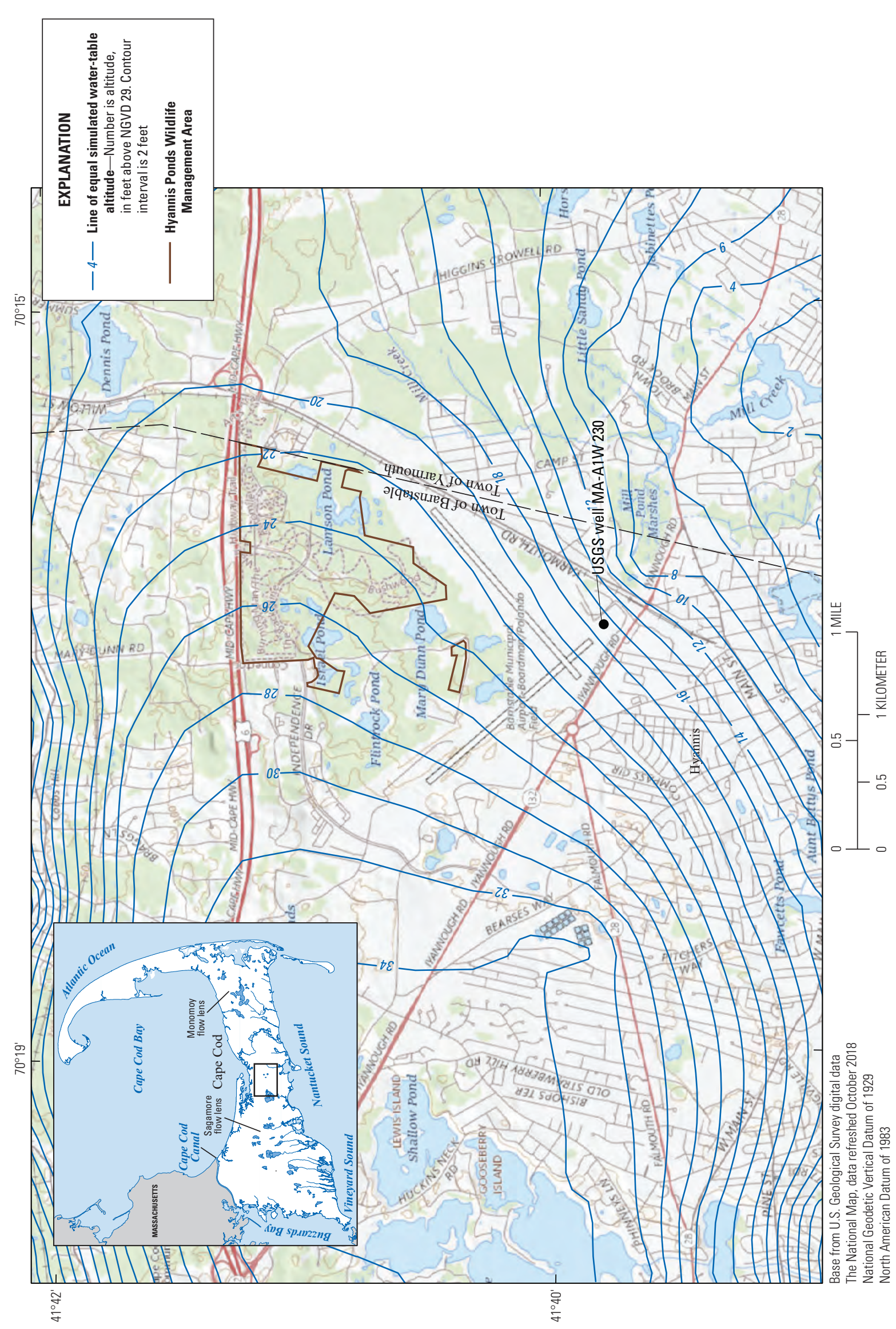


flexibility in the supply system. Natural-resources managers at local and State agencies are concerned that the pumping could cause changes in water levels that would adversely affect the critical pond-shore habitat of the native rare and endangered plants.

The Town of Barnstable and the Massachusetts Division of Fisheries and Wildlife (MassWildlife) requested the assistance of the U.S. Geological Survey (USGS) in estimating possible water-level changes for several pumping scenarios that included the proposed wells in the HPWMA. A USGS three-dimensional steady-state groundwater-flow model (Walter and others, 2016) was used to simulate average long-term changes in the water-table position, relative to the position for current (2015) withdrawals and recharge of wastewater return flow, that could result from the proposed pumping scenarios.

\section{Purpose and Scope}

The purpose of this report is to present the simulated changes in the water-table position and in pond levels relative to 2015 pumping and wastewater-recharge conditions for various scenarios for withdrawals and wastewater return flows proposed by the HWS, including the proposed addition of two supply wells in the HPWMA. The report also describes the groundwater-flow model, including modifications made to the model described by Walter and others (2016), and discusses the limitations of the modeling analysis. The documentation and input files for the modified model are available in McCobb and Walter (2019).

\section{Geographic and Hydrologic Setting}

The ponds in and near the HPWMA are on the Sagamore flow lens of the Cape Cod aquifer. Near the ponds, the water table is about 26 feet ( $\mathrm{ft}$ ) above sea level (altitudes in this report are relative to the National Geodetic Vertical Datum of 1929) and forms a divide just to the north of the HPWMA (fig. 1). Groundwater flows from the high points along the divide toward discharge areas at streams, wetlands, saltwater marshes, and coastal bays. The ponds occupy glacial kettlehole depressions that intersect the water table and exchange water with the aquifer by seepage through the pond bottoms. The deeper parts of the ponds are lined with fine-grained organic sediments that may impede this exchange and, at times of low water, cause the pond levels to be higher than the surrounding water table (McHorney, 1997; IEP, Inc., 1990).

The aquifer near the HPWMA is composed of saturated unconsolidated glacial sand, gravel, silt, and clay sediments that are about $320 \mathrm{ft}$ thick and lie on granitic bedrock (LeBlanc and others, 1986; Oldale, 1992; Walter and others, 2016). Sand and gravel predominate in the shallow part of the aquifer, although geologic borings drilled for water-supply testing have encountered a fine sand and silt layer at an altitude of about $4 \mathrm{ft}$ to $-13 \mathrm{ft}$; the thickness and areal extent of the layer are uncertain (McHorney, 1997; boring logs on file at the U.S. Geological Survey, Northborough, Mass.). The average natural recharge to the aquifer from precipitation is about 28 inches per year (in/yr) (Walter and Whealan, 2005). The water table fluctuates about 1-3 ft seasonally, and more between wet periods and droughts. The long-term water-level range observed in USGS monitoring well MA-A1W 230 (fig. 1) for the period 1958-2010 is $7.1 \mathrm{ft}$.

The ponds of interest are in and near the HPWMA in the area between the Barnstable Municipal Airport and Route 6 (fig. 2). The areas of the three largest ponds-Mary Dunn, Lamson, and Israel Ponds - are 18.0, 12.3, and 8.1 acres, respectively (Cape Cod Commission, 2008). Several small ponds are entirely within the HPWMA. The ponds generally are shallow. The maximum depth of Mary Dunn Pond, for example, varies temporally between about 6 and $11 \mathrm{ft}$ (McHorney and Neill, 2007; Cape Cod Commission, 2008). The larger ponds are well connected hydraulically to the groundwater system, whereas some of the smaller ponds may be less well connected to the saturated zone of the aquifer, especially when the water table is low (McHorney, 1997).

Drinking water was pumped from 96 wells and one surface reservoir in the Sagamore flow lens in 2015 for distribution through public water-supply systems (appendix 1, table 1.1). Most of the wells draw water from the upper $60 \mathrm{ft}$ of the saturated sand and gravel. Total annual withdrawals and days pumped in 2015 varied by well; average withdrawal rates (determined by dividing the annual withdrawals by 365 days and 1,440 minutes per day) ranged from about 56 to 298 gallons per minute ( $\mathrm{gal} / \mathrm{min}$ ) for individual wells. About two-thirds of the total annual groundwater withdrawals occurs between May and September (Walter and Whealan, 2005). The HWS in the town of Barnstable and the Yarmouth Water Department in the adjacent town of Yarmouth to the east both have wells near the HPWMA (fig. 3). Wastewater is recharged to the aquifer through individual septic systems and infiltration beds at the Barnstable Water Pollution Control Facility (WPCF) (fig. 3). In 2015, an average of $1,052 \mathrm{gal} / \mathrm{min}$ of wastewater was discharged to the infiltration beds at the Barnstable WPCF and assumed to recharge the aquifer with minimal loss to evaporation.

\section{Pumping and Wastewater Return-Flow Scenarios}

The pumping from the 96 wells and one surface reservoir for drinking water and the distribution of wastewater return flow to the aquifer by disposal at WPCFs and septic systems in 2015 were used as the reference hydrologic-stress condition in this study. The 2015 period was selected as the reference time period because the locations and withdrawals for the HWS during this period were considered more representative of the recent operation of the system than the 2010 period when several HWS wells were temporarily offline. Information about the locations, well-screen depths, and total water withdrawals 


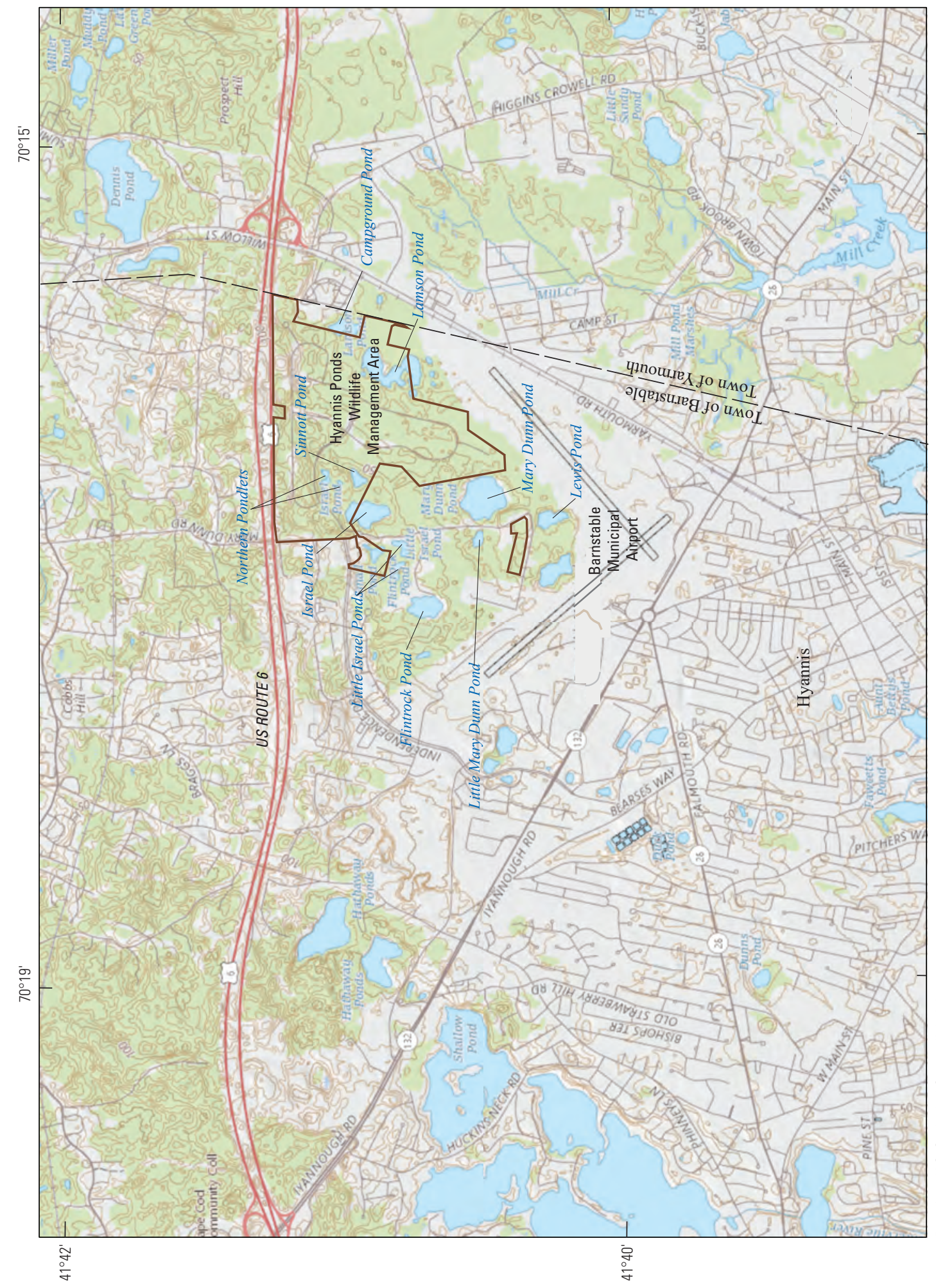

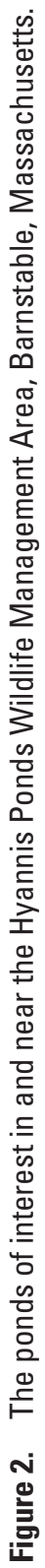




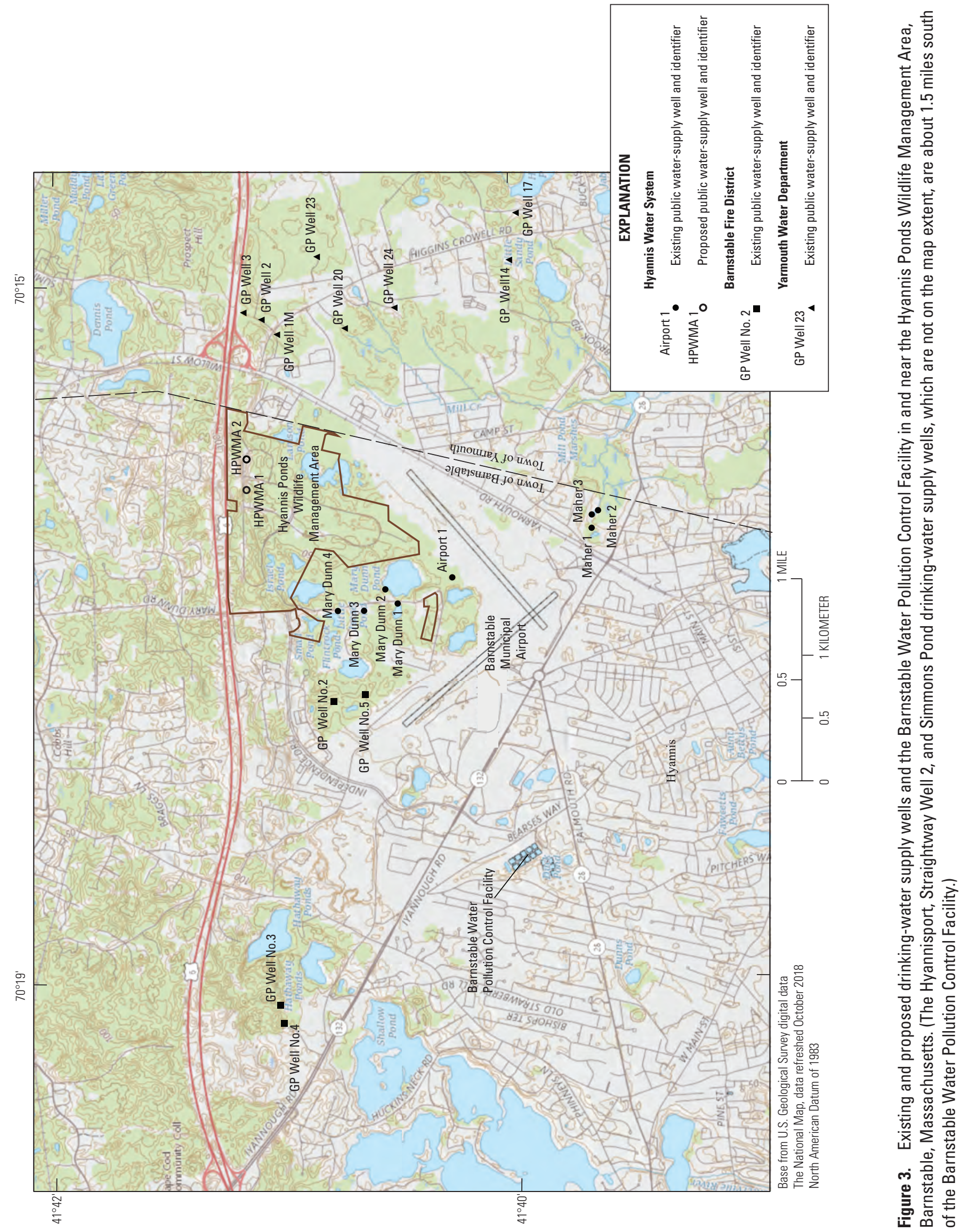


Simulated Water-Table and Pond-Level Responses to Proposed Public Water-Supply Withdrawals, Barnstable, Mass.

by location for 2015 were obtained from various sources, including the Massachusetts Departments of Environmental Protection (MassDEP) and Conservation and Recreation, the Cape Cod Commission, USGS databases, and water suppliers (The well characteristics and withdrawal rates for the wells that were pumped for drinking water in 2015 and are included in the groundwater simulation of the reference condition are documented in appendix 1, table 1.1).

Wastewater return-flow rates for 2015 at the WPFCs, including the Barnstable WPFC, were obtained from MassDEP and the WPCFs. The portion of the total return flow recharged to the aquifer through individual septic systems was determined for each area served by a water-supply system by the following steps: (1) The total volume pumped was reduced by 15 percent (10 percent for the HWS and Barnstable Fire District [BFD]) to account for consumptive water use (for example, lawn irrigation); (2) the total water discharged at WPCFs was subtracted from the resulting total wastewater return flow; and (3) the remaining return flow was distributed over the portion of the water-system service area that relies on septic systems for wastewater disposal by distributing the flow spatially in proportion to parcel-scale water use as metered by the water suppliers. A slightly lower consumptive water use was assumed for the HWS and BFD because of the greater urban development in the eastern part of the town of Barnstable than in most other areas of Cape Cod. The model-grid cells where return flow is recharged through septic systems are documented in the files of the model archive (McCobb and Walter, 2019). For areas served by domestic wells and septic systems, wastewater return flows to the septic systems were assumed to equal withdrawals from the wells, thus resulting in no net hydrologic stress in these areas. Additional descriptions of this approach are included in Walter and Whealan (2005), Walter and others (2016), and Walter and others (2019).

The proposed scenarios for future withdrawals by the HWS from its existing and proposed wells were developed by the HWS with assistance from the Cape Cod Commission. The only changes included in the simulations were those proposed by the HWS to the water withdrawals and wastewater return flows of the 2015 reference condition. Withdrawal rates and wastewater return flows for areas served by other water systems were not changed from the 2015 rates. The 2015 reference condition and nine scenarios are summarized in table 1. The locations of the HWS wells, other drinking-water-supply wells on the map area, and the Barnstable WPCF are shown on figure 3 .

The nine scenarios can generally be divided into three groups:

- Scenarios 1-3 and 5A included withdrawals only from existing wells in the HWS. Changes from the 2015 reference condition were limited to the wells in the Mary Dunn wellfield and included the resumption of withdrawals from Mary Dunn 4, which was not pumped in 2015. Scenarios 1-3 included small (3-8 percent) increases in total annual withdrawals by the HWS; sce- nario $5 \mathrm{~A}$ included a 15 -percent increase in total annual withdrawals. To estimate the increase in wastewater return flow because of the increased withdrawals, the volume of increased withdrawals in each scenario was reduced by 10 percent to account for consumptive water use; 75 percent of the remaining withdrawals was added as return flow to the WPCF discharge, and the remaining 25 percent was distributed to septic systems. The increased return flow to septic systems was distributed to the same model cells that received return flow for the 2015 reference condition.

- Scenarios 4-6 included the addition of the two proposed wells in the HPWMA (identified as wells HPWMA 1 and HPWMA 2 in table 1 and on fig. 3). Scenarios 4-6 included changes from the 2015 reference condition only to withdrawal rates from the wells in the Mary Dunn wellfield and the addition of the two proposed HPWMA wells. These changes resulted in increases in total annual withdrawals by the HWS of 8-16 percent more than the 2015 reference condition. The additional wastewater return flow was allocated to the WPCF and septic systems as described for scenarios 1-3.

- Scenarios 7-7A included adjustments to all the wells in the HWS and increases in total annual withdrawals by the HWS of 34 percent more than the 2015 reference condition. The additional wastewater return flow for scenario 7 was allocated to the WPCF and septic systems as described for scenarios 1-3. For scenario 7A, 75 percent of the total withdrawals for the HWS, after adjusting the total HWS withdrawals for the 10-percent consumptive water use, was discharged to the WPCF to represent a condition in which the portion of total HWS withdrawals discharged to the WPCF increased as urbanization increased and the sewer system was extended into areas presently served by septic systems. The balance was allocated to the septic systems.

The simulated locations and screened intervals of the proposed wells in the HPWMA were selected by the HWS on the basis of several factors, including the simulated waterlevel response maps discussed in the section "Pond-Level Responses to Production-Well Location," hydrogeologic information available from McHorney (1997), and lithologic observations and aquifer tests from water-supply investigations near the HPWMA, available from IEP, Inc. (1990) and other unpublished engineering reports in the files of the HWS. The screened intervals of the proposed wells used in the simulations of the nine scenarios correspond to layer 4 in the groundwater-flow model (the layers of which are described in the section "Groundwater-Flow Model"). The characteristics of the proposed HPWMA wells as simulated in this study are shown in table 2. 


\section{Groundwater Model and Simulation Approach}

The USGS MODFLOW (Harbaugh, 2005) threedimensional, steady-state groundwater-flow model described in Walter and others (2016) was used to simulate the response of water-table altitudes and pond levels to proposed changes in withdrawal and wastewater return-flow rates from those of the 2015 reference condition. The model is described in detail by Walter and others (2016). Changes made to the model and the simulation approach are described in this section and in appendix 1 .

\section{Groundwater-Flow Model}

The groundwater-flow model simulates steady-state flow in the Sagamore and Monomoy flow lenses (fig. 1 and appendix 1, fig. 1.1) of the Cape Cod aquifer (Walter and others, 2016). The upper boundary of the simulated groundwater system is the water table. The lower boundary is consolidated granitic bedrock or the freshwater/saltwater interface. The source of freshwater is recharge from precipitation and wastewater return flow. Groundwater discharges from the aquifer at streams, lakes, wetlands, coastal saltwater bodies, and production wells. Sources balance discharges in the steady-state model, and hydrologic conditions - water levels, streamflow, recharge, and discharge - are constant. Changes with time are not represented or simulated in the steady-state model.

The original groundwater-flow model presented in Walter and others (2016) used a constant natural recharge rate and 2010 withdrawal rates and locations. The original model was calibrated to observations of hydraulic head and streamflow made in 1995-2000. Walter and others (2016) indicated that pumping stresses and wastewater return flow in 2010 were similar to those in 1995-2000. For this study, the original model was modified to include a spatially variable rate of natural recharge. The spatial recharge distribution for this study was estimated by using the Soil-Water-Balance (SWB) computer code described in Walter and others (2016) and Westenbroek and others (2010). The modified model was recalibrated by using the same withdrawal rates and locations (appendix 1, table 1.1), return-flow rates and locations, and observations of heads and streamflow as those used by Walter and others (2016). The recalibration caused only minor adjustments in model parameters. The modifications and recalibration are described in appendix 1 and in McCobb and Walter (2019).

The model grid has a uniform horizontal discretization of $400 \mathrm{ft}$ (fig. 4) and consists of 25 layers that are 8-100 ft thick; the uppermost 21 layers are active within the area of the HPWMA. Layers 22-25 are truncated by the bedrock and are inactive near the HPWMA. Layers that change thickness across the model domain were used rather than horizontal layers (Walter and others, 2016). The altitudes of the tops and bottoms of the layers and the calibrated horizontal hydraulic conductivity for the layers at a representative model cell (fig. 4) near the HPWMA are shown in table 3. Six of the larger ponds - Israel, Flintrock, Lamson, Lewis, and Mary Dunn Ponds, and an unnamed pond west of Lewis Pond - are represented as zones of high hydraulic conductivity (fig. 4), whereas the smaller ponds are not represented explicitly because they generally are very shallow and smaller in area than a model-grid cell. The ponds are assumed to be well connected to the groundwater system so that pond levels reflect the adjacent water-table altitudes. Most drinking-water supply wells near the HPWMA have screens 8-20 ft long with midpoints set within 24-62 ft of the water table (within model layers 1-6) (McCobb and Walter, 2019).

\section{Simulation Approach}

The groundwater-flow model as presented by Walter and others (2016) and modified as described in appendix 1 and in McCobb and Walter (2019) was applied through several steps to simulate the response of the hydrologic system to the proposed pumping scenarios.

1. The modified calibrated model was run with 2015 withdrawal and wastewater return-flow rates (appendix 1, table 1.1) to obtain a reference condition for comparison to the proposed pumping scenarios. Withdrawal and wastewater return-flow rates for 2015 were obtained from MassDEP and the WPCFs. Water-supply wells that were not included in the model presented by Walter and others (2016) because they were not used in 2010 or were installed since 2010 were identified, and their locations and screened intervals were added to the input files.

2. The model with the 2015 rates was used to prepare maps of simulated water-level responses at six ponds to pumping a hypothetical well at various locations in and near the HPWMA. The response map for a given pond shows the drawdowns in the pond for pumping the hypothetical well at various locations on the model grid. A separate simulation was made for each location of the hypothetical well - a total of 87 separate steady-state model runs. The response maps were an intermediate product used by the HWS to assist in their selection of locations for proposed wells in the HPWMA.

3. The proposed pumping scenarios were simulated in individual model runs by using the modified calibrated model. Only the withdrawal rates for the wells in the HWS and wastewater return-flow rates for the area served by the HWS were changed from the 2015 reference condition rates for each scenario. Withdrawal rates and well locations for other nearby water systems and wastewater return-flow rates for their water-service areas were held constant at their 2015 rates; this approach focused the analysis of water-level changes on those caused by the scenarios proposed by the HWS. 


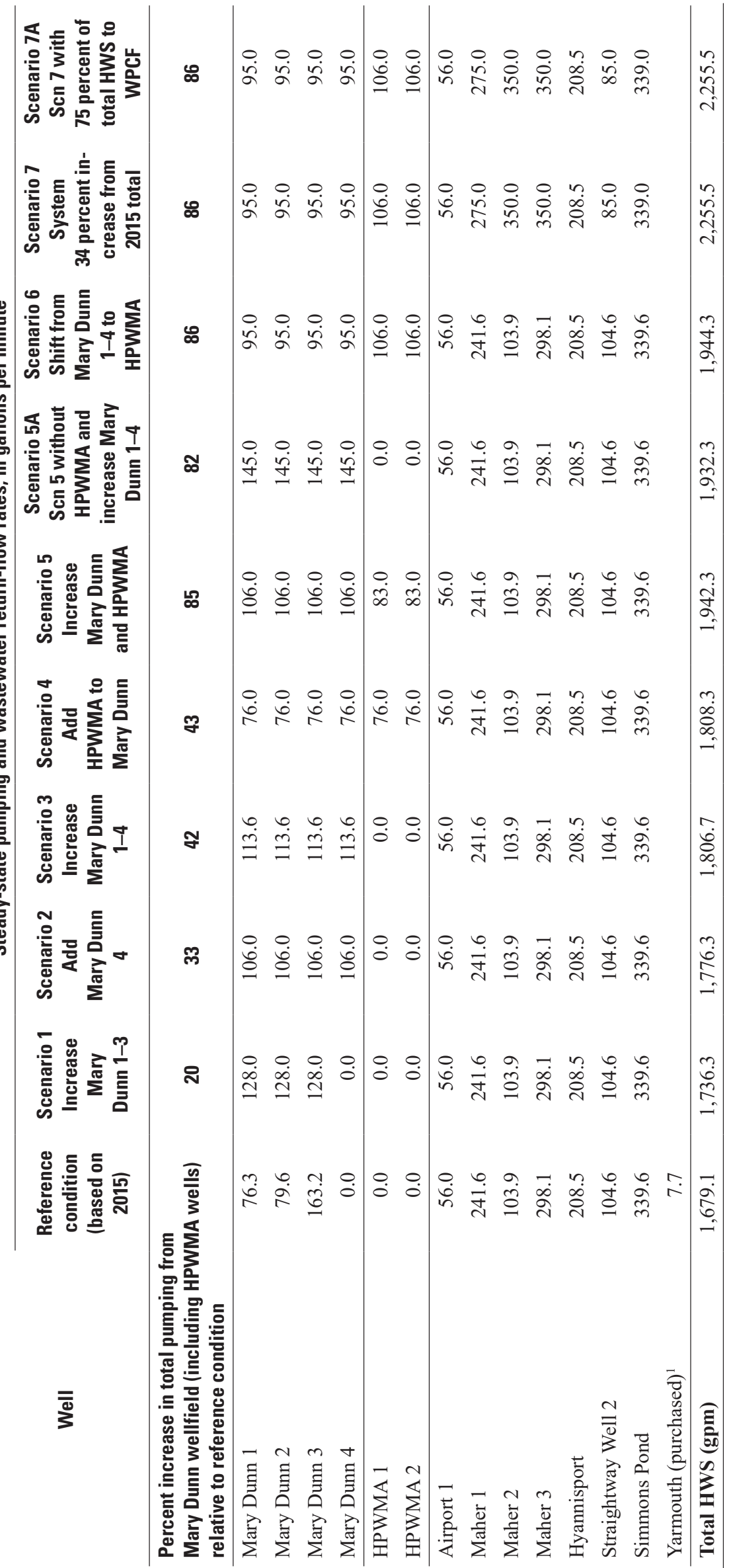




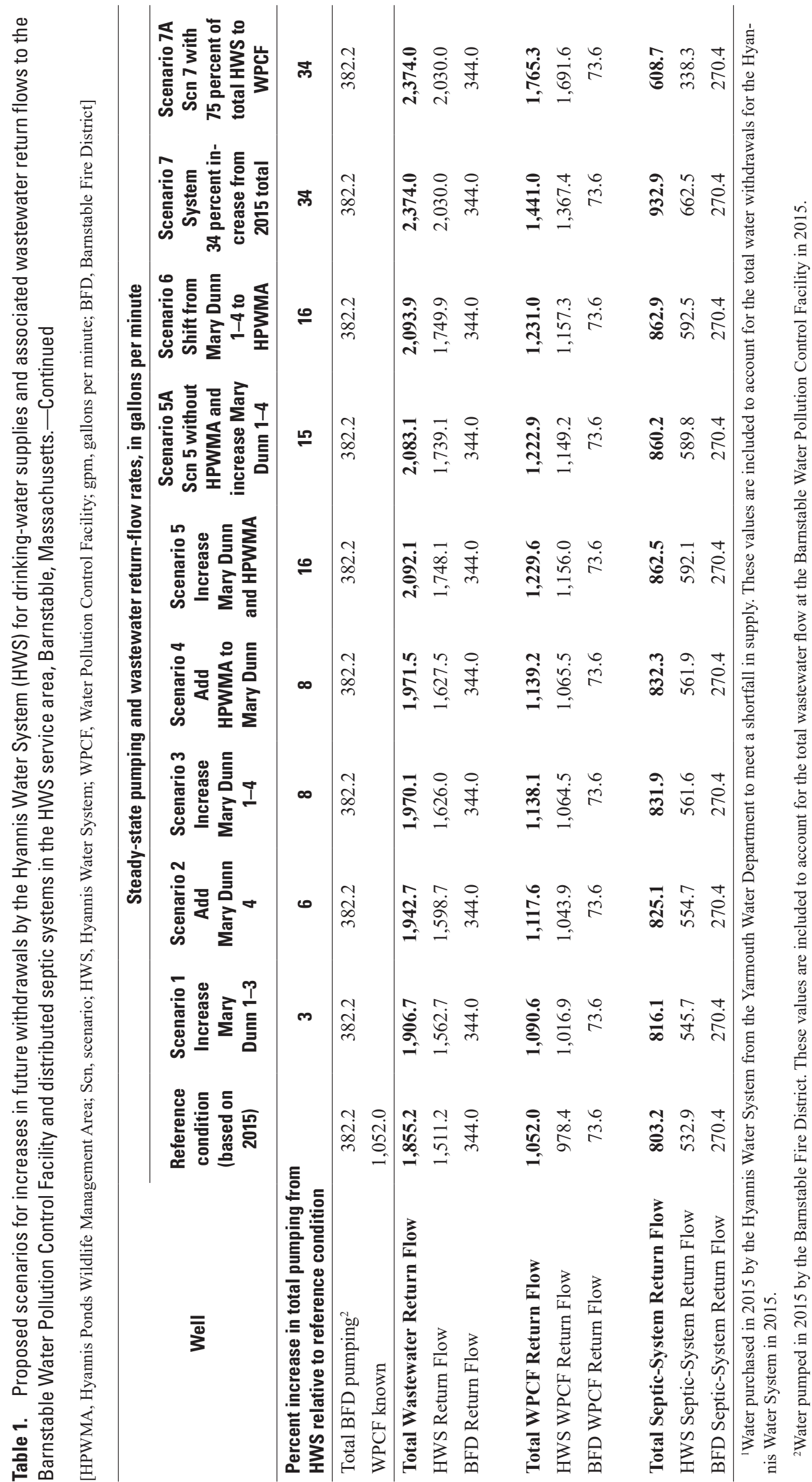


Table 2. Simulated locations and altitudes of screened intervals for the two proposed water-supply wells in the Hyannis Ponds Wildlife Management Area, Barnstable, Massachusetts.

[Latitude and longitude relative to the North American Datum of 1927. Altitude relative to the National Geodetic Vertical Datum of 1929. HPWMA, Hyannis Ponds Wildlife Management Area; dd mm ss.ss, degrees, minutes, and decimal seconds]

\begin{tabular}{cccccccc}
\hline Well & Model row & Model column & Model layer & $\begin{array}{c}\text { Latitude, } \\
\text { dd mm ss.ss }\end{array}$ & $\begin{array}{c}\text { Longitude, } \\
\text { dd mm ss.ss }\end{array}$ & $\begin{array}{c}\text { Altitude of top of } \\
\text { simulated screen, } \\
\text { in feet }\end{array}$ & $\begin{array}{c}\text { Altitude of bottom of } \\
\text { simulated screen, } \\
\text { in feet }\end{array}$ \\
\hline HPWMA 1 & 162 & 310 & 4 & 414108.51 & 701611.11 & -17.56 & -29.72 \\
HPWMA 2 & 162 & 312 & 4 & 414108.51 & 701600.56 & -18.04 & -30.17 \\
\hline
\end{tabular}

Table 3. Top and bottom altitudes and horizontal hydraulic conductivities of the layers in the modified groundwater-flow model for a representative model cell in the Hyannis Ponds Wildlife Management Area, Barnstable, Massachusetts.

[Location of the representative model cell is shown on figure 4. Altitudes are relative to the National Geodetic Vertical Datum of 1929. $\mathrm{K}_{\mathrm{h}}$, horizontal hydraulic conductivity]

\begin{tabular}{|c|c|c|c|c|}
\hline Model layer & $\begin{array}{l}\text { Altitude of top of layer, } \\
\text { in feet }\end{array}$ & $\begin{array}{l}\text { Altitude of bottom of layer, } \\
\text { in feet }\end{array}$ & $\begin{array}{l}\text { Thickness of layer, } \\
\text { in feet }\end{array}$ & $\begin{array}{l}\text { Calibrated } K_{h^{\prime}} \\
\text { in feet per day }\end{array}$ \\
\hline 1 & Water table & 7.5 & 15.0 & 109 \\
\hline 2 & 7.5 & -4.7 & 12.2 & 109 \\
\hline 3 & -4.7 & -16.9 & 12.2 & 109 \\
\hline 4 & -16.9 & -29.1 & 12.2 & 109 \\
\hline 5 & -29.1 & -41.3 & 12.2 & 109 \\
\hline 6 & -41.3 & -53.5 & 12.2 & 109 \\
\hline 7 & -53.5 & -65.7 & 12.2 & 49 \\
\hline 8 & -65.7 & -77.9 & 12.2 & 49 \\
\hline 9 & -77.9 & -90.1 & 12.2 & 49 \\
\hline 10 & -90.1 & -102.4 & 12.2 & 49 \\
\hline 11 & -102.4 & -114.6 & 12.2 & 49 \\
\hline 12 & -114.6 & -126.8 & 12.2 & 49 \\
\hline 13 & -126.8 & -139.0 & 12.2 & 49 \\
\hline 14 & -139.0 & -151.2 & 12.2 & 49 \\
\hline 15 & -151.2 & -163.4 & 12.2 & 49 \\
\hline 16 & -163.4 & -175.6 & 12.2 & 19 \\
\hline 17 & -175.6 & -187.8 & 12.2 & 19 \\
\hline 18 & -187.8 & -200.0 & 12.2 & 19 \\
\hline 19 & -200.0 & -230.0 & 30.0 & 19 \\
\hline 20 & -230.0 & -260.0 & 30.0 & 19 \\
\hline 21 & -260.0 & -290.0 & 30.0 & 19 \\
\hline 22 & -290.0 & -298.3 & 8.3 & Inactive \\
\hline 23 & -298.3 & -370.0 & 71.7 & Inactive \\
\hline 24 & -370.0 & -420.0 & 50.0 & Inactive \\
\hline 25 & -420.0 & -520.0 & 100.0 & Inactive \\
\hline
\end{tabular}




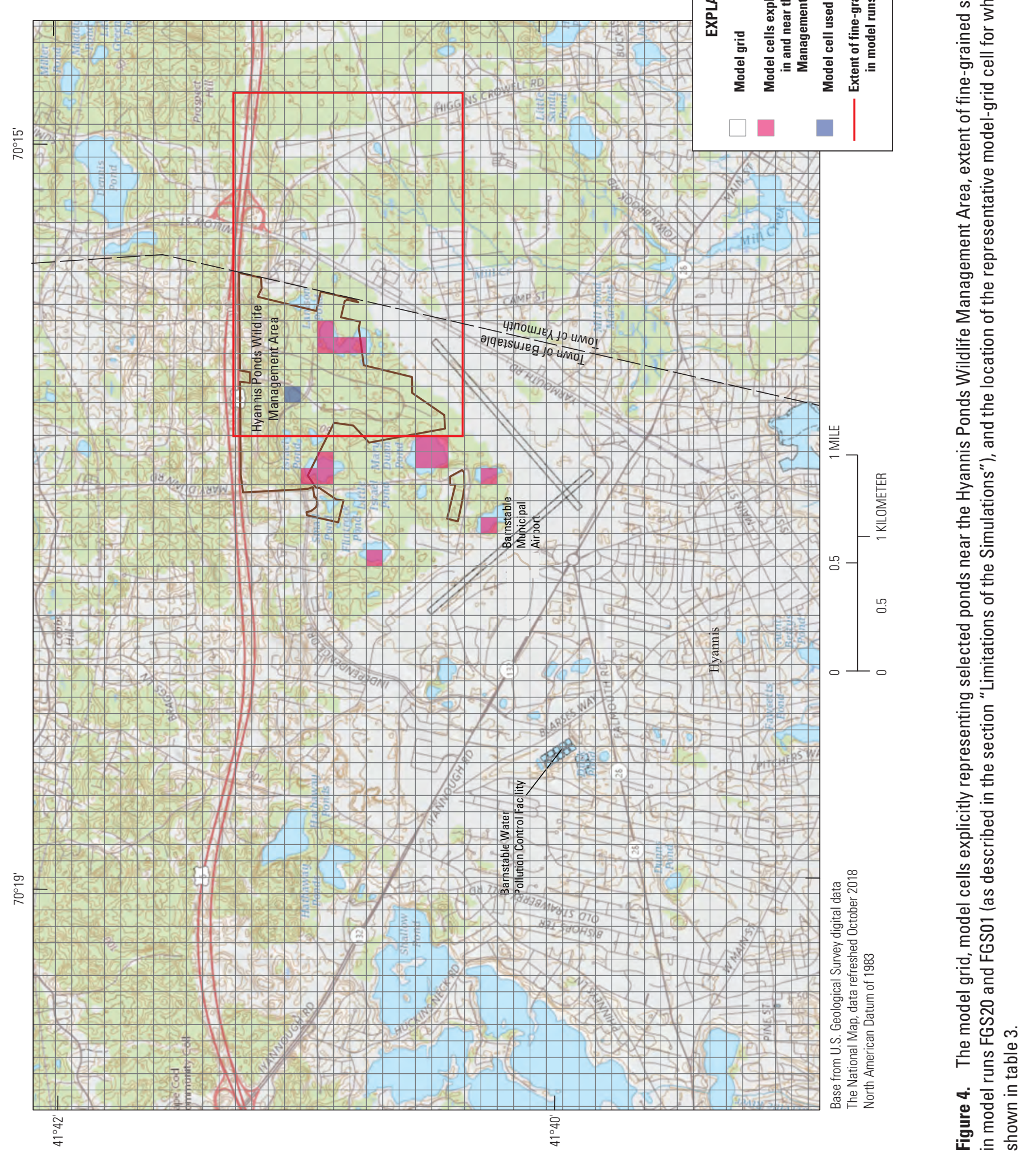




\section{Simulated Pond-Level and Water-Table Responses}

The steady-state groundwater-flow model described by Walter and others (2016) and modified as described in this report was used to simulate the response of the water table and water levels in ponds hydraulically connected to the groundwater system to proposed groundwater withdrawals. The results of the simulations are presented in this section as water-level response maps for six ponds to withdrawals at various locations, maps of water-table altitudes and drawdowns for various pumping scenarios, and tables of waterlevel changes for model cells in the ponds of interest.

\section{Pond-Level Responses to Production-Well Locations}

The water-table response maps for Israel, Mary Dunn, Lamson, Campground, and Little Israel Ponds and a group of several small ponds, known locally as the "Northern Pondlets" and which include Smiley Pond, are shown on figure 5. The drawdown at a given pond caused by pumping a well at a given model-cell location is shown by shading of the model cell containing the well; darker shading in a model cell indicates greater drawdown. The hypothetical well that was moved from cell to cell, each move requiring a new simulation, was screened in model layer 3 and pumped at $100 \mathrm{gal} / \mathrm{min}$. The wastewater discharge at the Barnstable WPCF was increased by $100 \mathrm{gal} / \mathrm{min}$ to account for the additional withdrawal. The pumping rate, screened interval, and discharge of 100 percent of the additional withdrawal to the WPCF were chosen arbitrarily for illustrative purposes because the pumping and wastewater return-flow scenarios had not yet been proposed when the response maps were prepared. The screen was approximately centered in the permeable upper part of the aquifer (table 3 ) for the simulations. The screened interval was set at a slightly higher altitude than that ultimately used for the proposed HPWMA wells (layer 4) in the simulations of the nine scenarios. The responses of the pond levels to pumping at the two intervals are not likely to differ significantly, given the low anisotropy of the aquifer sediments, unless the wells are placed very close to the ponds.

The response maps show that withdrawals from locations near ponds result in greater pond-level drawdowns (darker shading) than withdrawals from locations farther from ponds. Small ponds, such as the Northern Pondlets, are more sensitive to nearby withdrawals than large ponds, such as Mary Dunn Pond, because the drawdown effects are distributed over a greater area near the larger ponds.

As an example of how the response maps can be used to guide the selection of locations for the proposed production wells, the cell-by-cell water-table responses for Mary Dunn, Israel, and Lamson Ponds in figure 5 were added to create a composite response map for the three ponds (fig. 6). The lighter shading in the northeastern corner of the map indicates that withdrawals from this area will have a lower collective effect on the levels of the three ponds than withdrawals from the western and southern areas of the HPWMA.

\section{Water-Table Response to Pumping and Wastewater Return-Flow Scenarios}

A steady-state simulation was run for each of the proposed scenarios for pumping and wastewater return flow shown in table 1. As an example, the simulated effect of pumping and wastewater return flow on the water-table configuration for scenario 4 is shown on figures 7 and 8 . Scenario 4 includes an 8-percent increase in total withdrawals by the HWS relative to the 2015 reference condition, with the entire increase caused by increased withdrawals from the four existing Mary Dunn wells and the two proposed HPWMA wells. The total withdrawal from the Mary Dunn area in scenario 4, which includes the two proposed wells in the HPWMA wells, is $456 \mathrm{gal} / \mathrm{min}$ - an increase of 43 percent above the total withdrawals from the Mary Dunn area in 2015. Production rates for the other wells in the HWS system were not changed from the 2015 condition in scenario 4. Wastewater return flow to the Barnstable WPCF and distributed to the unsewered water-service area was increased to account for the 8-percent increase in total withdrawals in scenario 4.

The shape of the simulated water-table contours changes only slightly at the regional scale between the 2015 reference and scenario 4 conditions (fig. 7). The largest shifts of the water-table contours are within and to the north of the HPWMA and near the Barnstable WPCF. The directions of groundwater flow, as inferred from the water-table gradient, also change only slightly, with the largest changes near the HPWMA and the Barnstable WPFC. The regional hydrologic divide between regions of generally northward and southward flow remains slightly south of Route 6, although flow directions change over smaller areas near the WPCF and Israel Pond.

The map of the change in the simulated water-table altitude between the 2015 reference condition and scenario 4 shows clearly the effects of changes in pumping and wastewater return-flow rates and locations (fig. 8). Water levels decline the most within the HPWMA and near Israel Pond where withdrawal rates were increased the most relative to the 2015 reference condition; water levels increase near the WPCF where return-flow rates also were increased. The largest simulated drawdown (decline in the water-table altitude) is about $1 \mathrm{ft}$ at the sites of the two proposed wells in the HPWMA, which is expected because pumping from this area was not included in the 2015 reference condition. The mounding (increase in altitude) of the water table at the WPCF is about $0.4 \mathrm{ft}$, which reflects the increase in wastewater disposal at the facility because of the 8-percent increase in total water withdrawals by the HWS for scenario 4. 

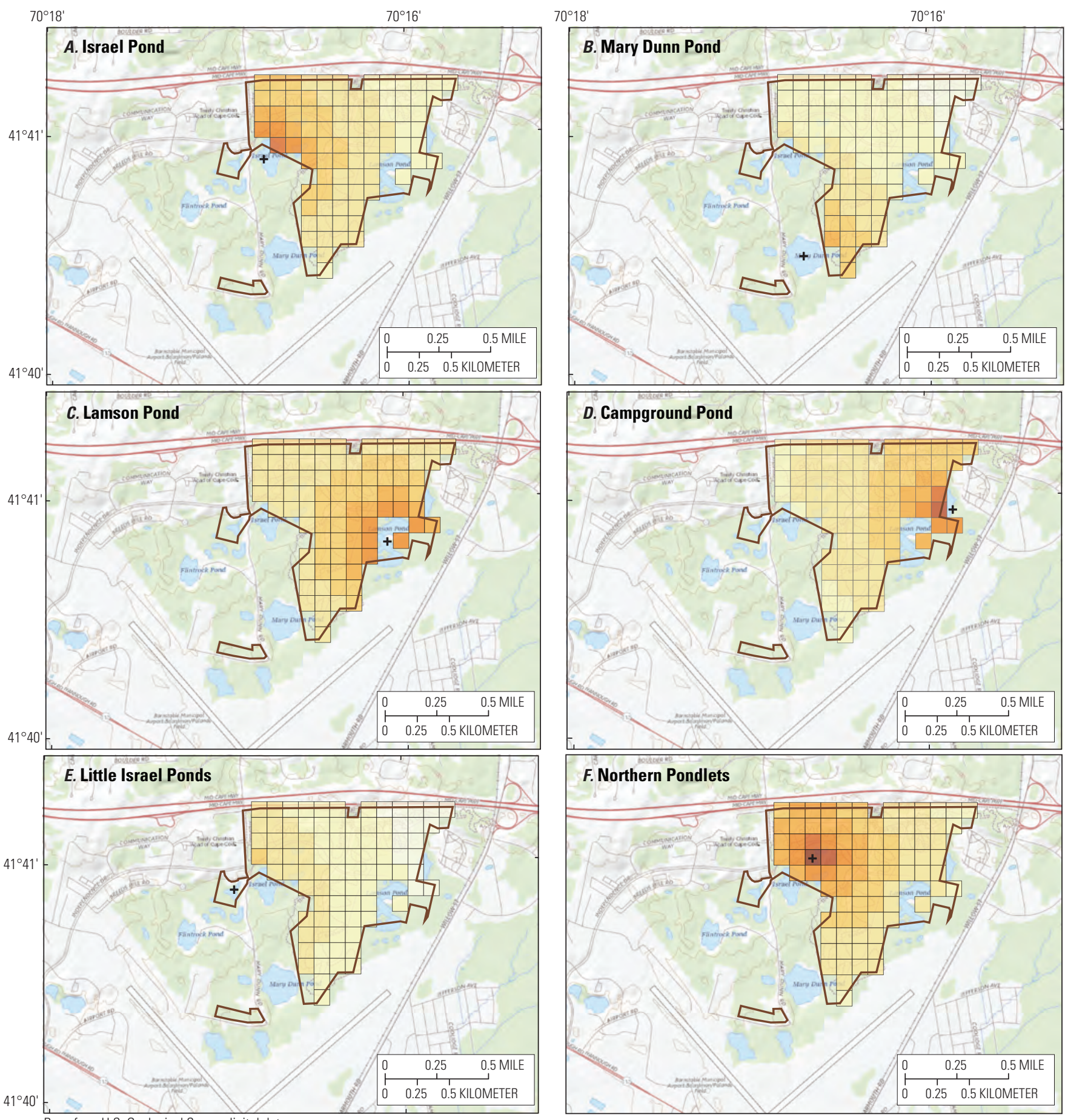

Base from U.S. Geological Survey digital data

The National Map, data refreshed October 2018

North American Datum of 1983

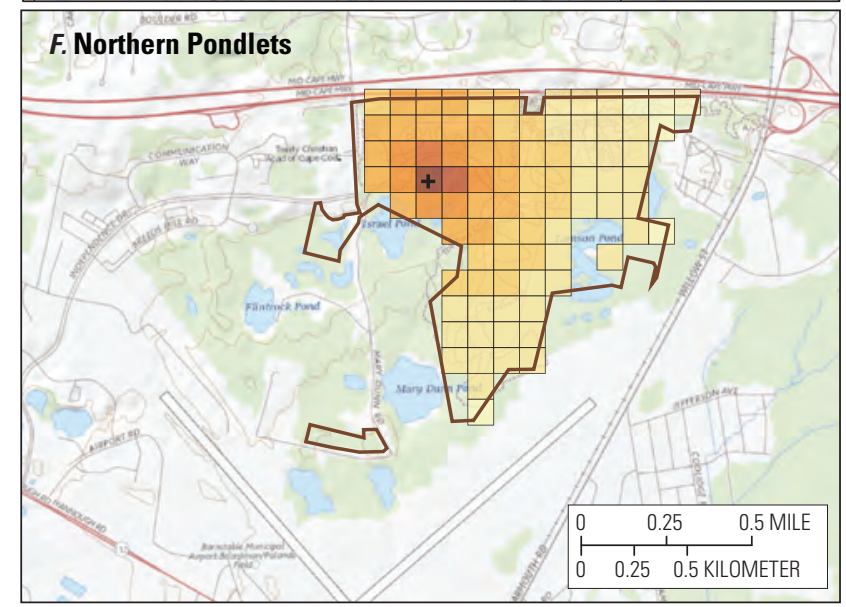

EXPLANATION

Simulated drawdown at six ponds near the Hyannis Ponds Wildlife Management Area, in feet - From single well pumping at 100 gallons per minute located at the model cell. Drawdown is relative to the 2015 pumping and wastewater return-flow reference condition

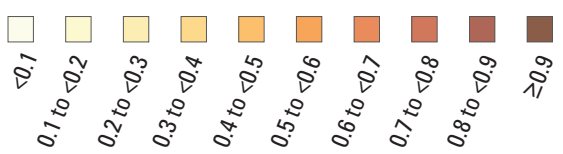

Hyannis Ponds Wildlife Management Area

+ Location of model cell used to track simulated drawdown for the pond indicated

Figure 5. Simulated water-level responses at $A$, Israel Pond, $B$, Mary Dunn Pond, $C$, Lamson Pond, $D$, Campground Pond, $E$, Little Israel Ponds, and $F$, the Northern Pondlets for pumping 100 gallons per minute from a well screened in model layer 3, Barnstable, Massachusetts. The color of each model cell represents the simulated water-table drawdown relative to the 2015 reference condition at the pond if a single, hypothetical production well is in the cell. The cross symbols indicate the model cells where simulated watertable drawdowns were recorded. 


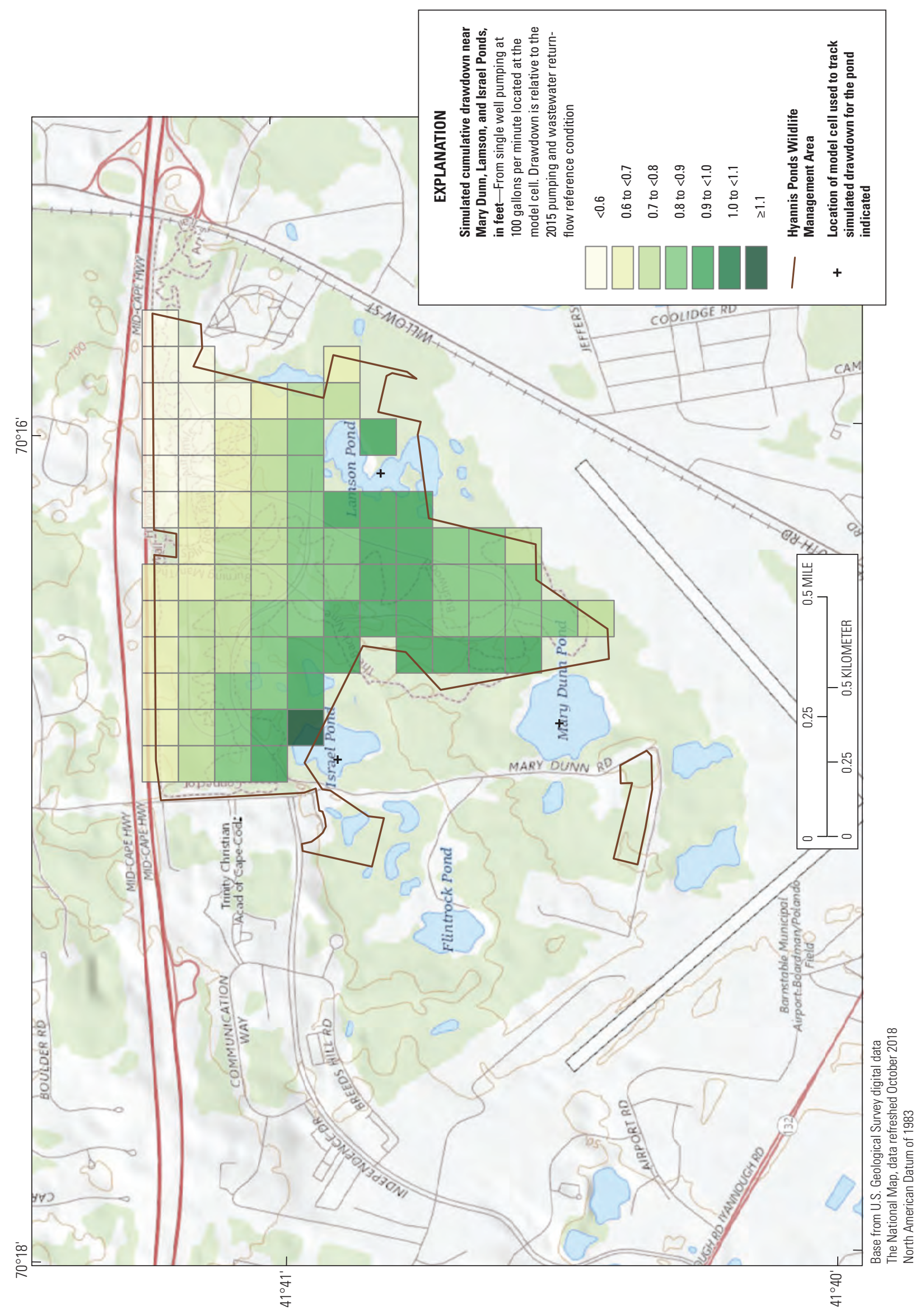

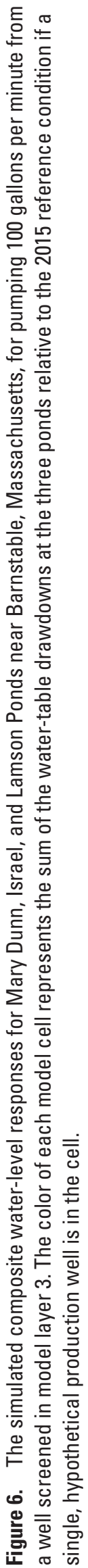




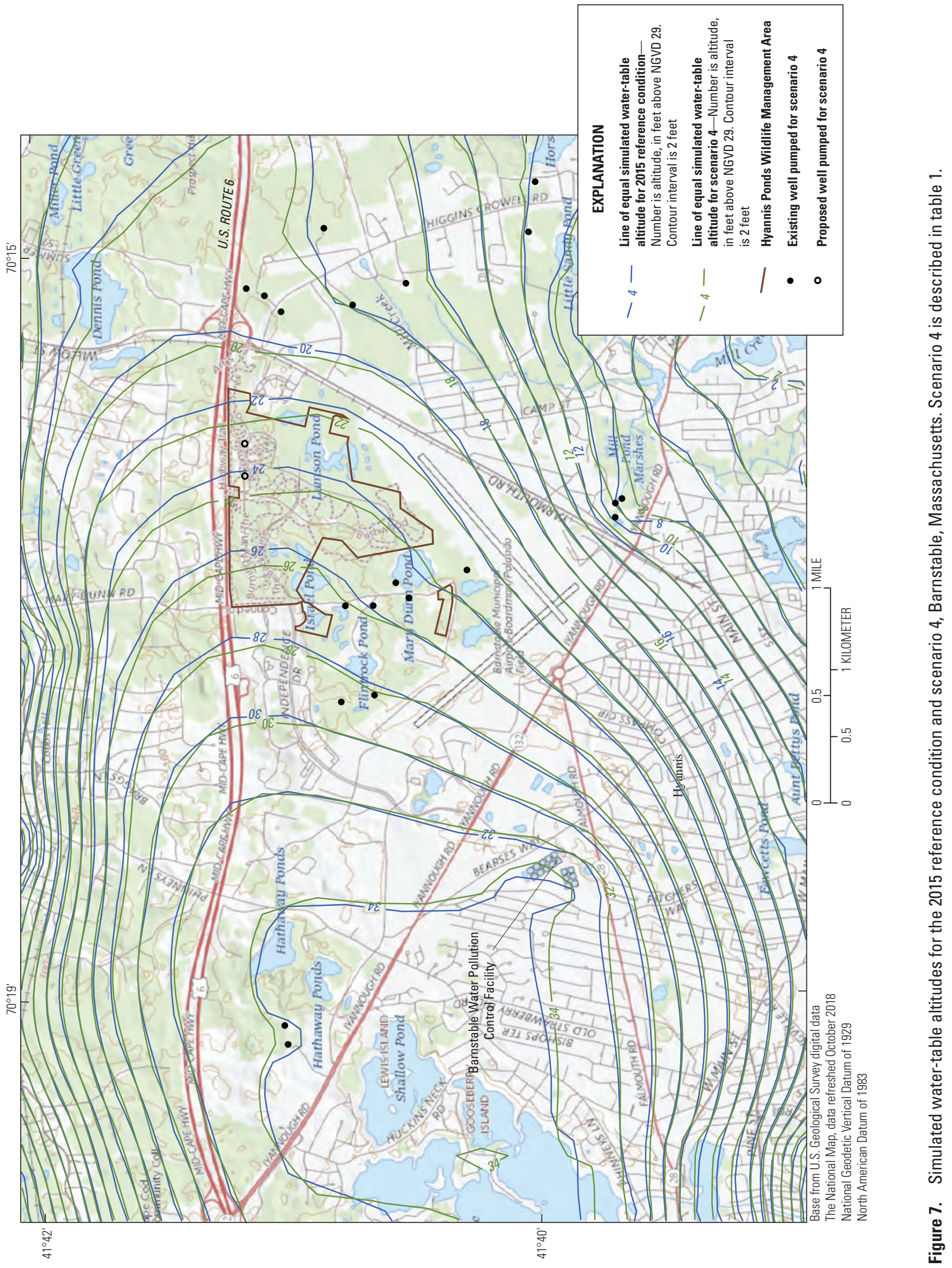




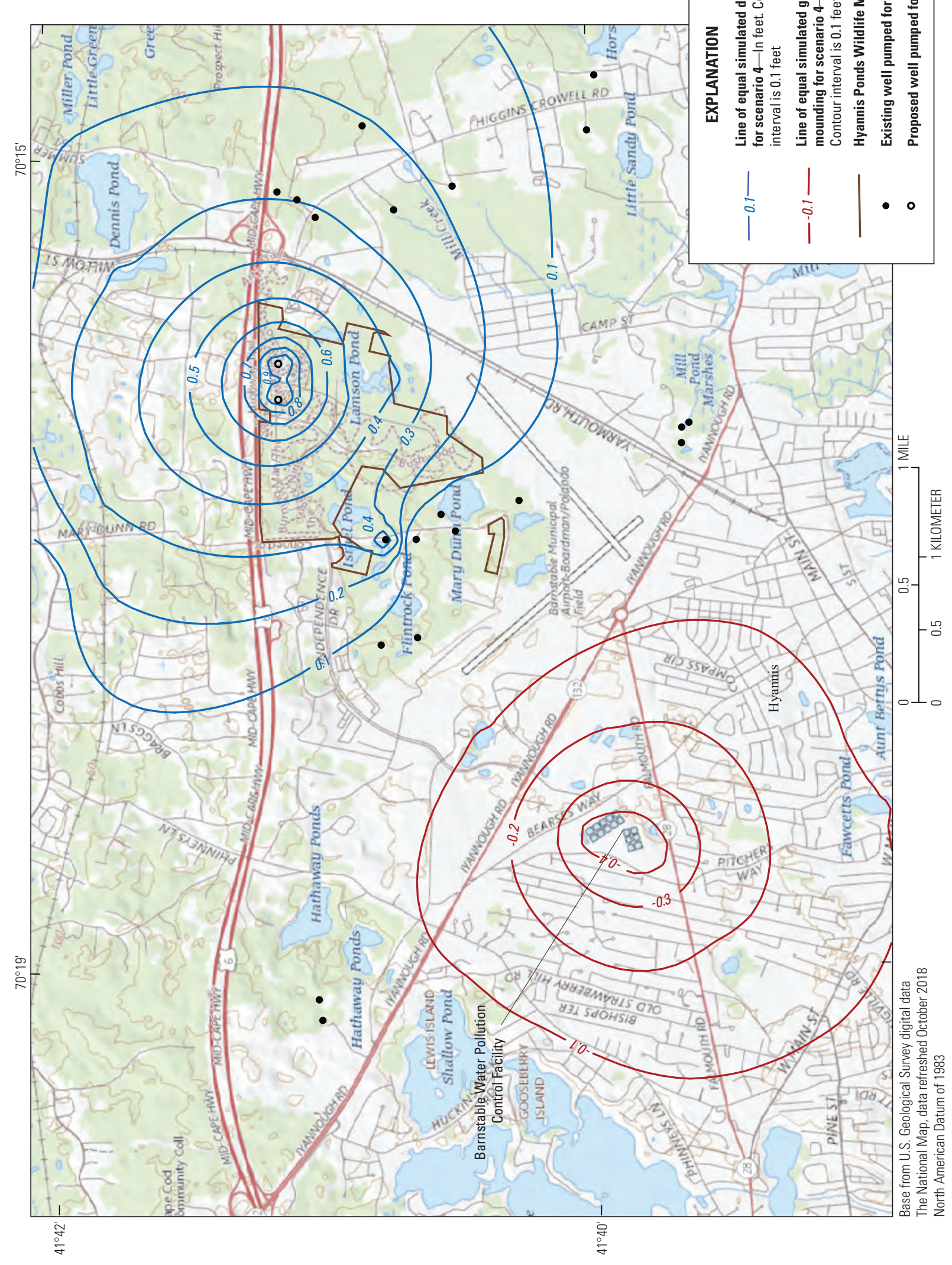

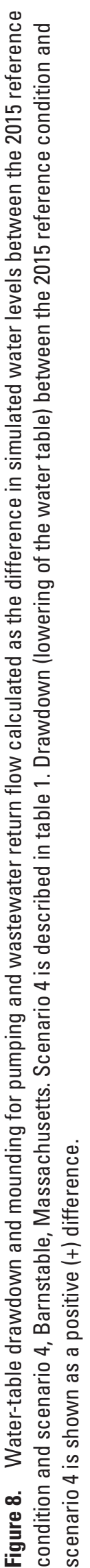


Table 4. Simulated water-table changes relative to the 2015 reference condition at selected ponds in and near the Hyannis Ponds Wildlife Management Area, Barnstable, Massachusetts, for the pumping and wastewater return-flow scenarios described in table 1.

[Pond locations are shown in figure 2. Drawdowns in feet; negative drawdowns represent mounding]

\begin{tabular}{lccccccccc}
\hline \multicolumn{1}{c}{ Pond } & Scenario 1 & Scenario 2 & Scenario 3 & Scenario 4 & Scenario 5 & Scenario 5A & Scenario 6 & Scenario 7 & Scenario 7A \\
\hline Israel Pond & 0.16 & 0.40 & 0.50 & 0.34 & 0.74 & 0.89 & 0.70 & 0.62 & 0.44 \\
Mary Dunn Pond & 0.43 & 0.42 & 0.55 & 0.07 & 0.61 & 1.11 & 0.47 & 0.45 & 0.26 \\
Lamson Pond & 0.14 & 0.23 & 0.29 & 0.46 & 0.74 & 0.54 & 0.80 & 0.78 & 0.68 \\
Little Mary Dunn Pond & 0.32 & 0.35 & 0.48 & -0.02 & 0.51 & 1.03 & 0.36 & 0.29 & 0.07 \\
Flintrock Pond & 0.13 & 0.29 & 0.38 & 0.08 & 0.42 & 0.73 & 0.33 & 0.18 & -0.08 \\
Campground Pond & 0.11 & 0.18 & 0.23 & 0.53 & 0.77 & 0.43 & 0.86 & 0.85 & 0.76 \\
Sinnott Pond & 0.16 & 0.35 & 0.44 & 0.38 & 0.76 & 0.80 & 0.75 & 0.68 & 0.52 \\
Northern Pondlets & 0.15 & 0.32 & 0.39 & 0.42 & 0.77 & 0.72 & 0.78 & 0.72 & 0.57 \\
Little Israel Ponds & 0.15 & 0.48 & 0.59 & 0.26 & 0.71 & 1.04 & 0.62 & 0.51 & 0.29 \\
Lewis Pond & 0.22 & 0.24 & 0.32 & 0.02 & 0.34 & 0.64 & 0.25 & 0.26 & 0.05 \\
\hline
\end{tabular}

The changes in simulated water-level altitudes for the model cells near the centers of 10 ponds of interest (fig. 2) for the nine scenarios (table 1) are shown in table 4 . The simulated changes range from a small water-table rise $(0.08 \mathrm{ft})$ at Flintrock Pond for scenario 7A to a decline of $1.11 \mathrm{ft}$ at Mary Dunn Pond for scenario 5A. The effect of adding the proposed HPWMA wells and reducing pumping from the four Mary Dunn wells (compare scenarios 3 and 4 in table 1) is to lower water levels at some ponds and increase water levels at other ponds relative to the water levels for the 2015 reference condition (table 4). Additional increases in pumping from the Mary Dunn and HPWMA wells (compare scenarios 4 and 5, table 1 , for example) generally cause water levels relative to the 2015 reference condition to decrease at the ponds of interest (table 4). Increases in pumping from the other wells in the HWS system while holding rates constant for the Mary Dunn and two proposed WMA wells (compare scenario 6 to scenarios 7 and $7 \mathrm{~A}$, table 1) cause water levels at all the ponds of interest to increase, despite the increase in total withdrawals for the water-supply system, because the wastewater return flow at the Barnstable WPCF is increased to account for the increased production from wells farther from the WMA, and a water-table mound forms that propagates outward from the area of focused wastewater recharge (see, for example, fig. 8).

\section{Limitations of the Simulations}

The steady-state three-dimensional model of groundwater flow described by Walter and others (2016) and modified for this project (appendix 1; McCobb and Walter, 2019) was used to simulate changes in water-table altitudes in and near the HPWMA that could result from proposed changes in rates and locations of withdrawals for public water supply and associated recharge of wastewater return flow. The model is a mathematical representation of the groundwater-flow system and is based on several assumptions and limitations.

The scenarios shown in table 1 include adjustments to the 2015 reference condition only for the HWS and associated wastewater return flow. Changes to locations and rates of withdrawals and wastewater return flow for other watersupply entities, especially those near the HPWMA, also could contribute to water-level changes in the area. Observed long-term changes in water levels at the ponds would include the effects of pumping and recharge of wastewater return flow in nearby areas and would complicate efforts to distinguish water-level changes caused by the operations of the HWS from changes caused by the operations of other water-supply and wastewater entities.

The groundwater-flow model simulates steady-state conditions only. Time-varying groundwater levels, streamflows, and hydrologic stresses such as natural recharge, pumping for water supply, and wastewater recharge, including seasonal variations in pumping and wastewater recharge, are not represented in the model. The simulated hydraulic heads and flows are at their long-term average conditions for the simulated withdrawal and return-flow rates of the reference condition and proposed scenarios. The assumption of steady-state conditions was used for this analysis because the particular concern addressed during this effort is a long-term shift in average pond levels caused by increased withdrawals and wastewater return flow that could alter the pond-shore habitat permanently; for example, lower water levels would decrease the habitat area by making the ponds smaller and shifting the shorelines from the present sandy areas to organicrich sediments deeper in the pond basins (Richard McHorney, oral commun., December 17, 2017). Potential changes to pond levels because of changes to seasonal and annual variations in pumping and wastewater return flow are also a concern. A transient groundwater-flow model that represents storage properties of the aquifer would be needed to examine the temporal 
response of pond levels to time-varying natural recharge, withdrawals, and wastewater return flows.

The hydraulic connections between the ponds and the groundwater system may affect the response of pond levels to water-table changes in the aquifer. The groundwater-flow model represents the larger ponds as hydraulically well connected to the aquifer. The smaller ponds are not represented explicitly in the model. The water-level changes shown in table 4 for the smaller ponds are the changes in the water table at model cells near the pond locations. IEP, Inc. (1990), McHorney (1997), and McHorney and Neill (2007) reported that fine-grained sediments on the bottom of some ponds may limit the exchange with the groundwater system and cause pond levels to be higher than the adjacent water table, especially during periods of declining water levels. Vertical hydraulic conductivities of the pond bottoms are likely higher in sandy areas near the shores than in deep areas where organic sediments are present (McHorney and Neill, 2007). A computer code such as the Lake Package described by Merritt and Konikow (2000) could be used to represent more explicitly the hydraulic connection between the ponds and aquifer during times of significant water-level changes. The effect of poorly permeable fine-grained sediments on long-term steadystate water levels at the ponds is not well understood, and it is possible that the drawdown at some ponds, especially the smaller ponds with limited sandy shorelines, could be less than predicted by the regional steady-state model.

Several field investigations reported the presence of fine-grained sediments at an altitude of about $4 \mathrm{ft}$ to $-13 \mathrm{ft}$ in parts of the Barnstable outwash plain (McHorney, 1997), including the area near the HPWMA. Two simulations based on scenario 4 (table 1) were run to examine the sensitivity of simulated water-level changes to the simulated extent and hydraulic properties of the fine-grained sediments. The hydraulic conductivity of model layer 2 in the approximate area of the HPWMA (fig. 4) was decreased in the two runs to 20 percent (model simulation FGS20) and 1 percent (model run FGS01) of that in the calibrated model. The inclusion of the less permeable layer changed simulated water levels by less than $0.2 \mathrm{ft}$ at the 10 ponds of interest. Further examination of the potential effects of the fine-grained sediments on the water-level response to pumping would require more information about the extent and hydraulic properties of the less permeable sediments.

The calibrated model simulates a smooth water table that slopes consistently eastward and southeastward near the HPWMA (fig. 7). McHorney (1997, figs. 4-5 and 7) reported water-table altitudes near Lamson Pond that are higher than water-table altitudes in the southern part of the HPWMA. The higher water levels were confirmed by an altitude survey of the wells and water-level measurements made in May 2018 (Thomas Cambareri, Cape Cod Commission, written commun., April 1, 2019). The cause of the difference between the simulated and observed water tables in this area is not known; potential causes could include unidentified hydrologic stresses and hydrogeologic characteristics of the pond-bottom and aquifer sediments. Further study of these potential causes was beyond the scope of this investigation.

The groundwater-flow model was originally designed and constructed to examine the regional effects of sea-level rise on the water table for the Sagamore and Monomoy flow lenses (Walter and others, 2016) and was not constructed specifically to represent the HPWMA and pumping from nearby watersupply wells. Data on the hydrogeologic characteristics of the aquifer and hydraulic heads and streamflows used to construct and calibrate the model were sparse near the HPWMA. Locations of production wells and water-level monitoring wells were approximated at the centers of the $400-\mathrm{ft}$ model cells (fig. 4), and the uniform model-grid spacing of $400 \mathrm{ft}$ is large compared to the areas of the smaller ponds. A smaller modelcell size and additional observations of groundwater and pond levels and aquifer and pond-bottom hydraulic characteristics might reduce uncertainties in the predicted responses to withdrawals obtained from the regional model. The smaller model-cell size might enable explicit representation of the smaller ponds and better characterization of hydraulic properties, such as the hydraulic conductivity of pond-bottom sediments, that affect the hydraulic connection between the ponds and the aquifer.

\section{Summary and Conclusions}

A three-dimensional steady-state groundwater-flow model was used to simulate changes in pond levels and the water table near the Hyannis Ponds Wildlife Management Area (HPWMA) that could result from proposed changes in withdrawals for water supply near the HPWMA, including the installation of additional wells in the HPWMA. The shoreline areas of about a dozen shallow ponds in and near the HPWMA are habitat for rare and endangered plants that have adapted to shifting pond shorelines. The ponds are hydraulically connected to the unconfined water-table aquifer. Pond levels rise and fall as the water table fluctuates in response to natural variations in recharge, nearby pumping for water supply, and recharge of wastewater return flow through septic systems and at water pollution control facilities.

The water managers for the Hyannis Water System (HWS) prepared nine scenarios for future withdrawals for water supply from an existing system of wells in the Hyannis area and two additional proposed wells in the HPWMA. The scenarios included total annual withdrawals from the well system that are 3-34 percent greater than withdrawals during 2015 , which is the reference period used for this study. The locations of the additional wells were selected by the HWS partly on the basis of maps prepared by using the model of the simulated water-level responses at six ponds to one well pumping at 100 gallons per minute at various locations in the HPWMA.

The simulated pond water-level changes for the nine scenarios relative to the levels for the 2015 reference condition 
at 10 ponds of interest ranged from small rises (less than 0.1 foot) at one pond each for two scenarios to declines (drawdowns) of 1.03-1.11 feet at three ponds for one scenario. The shape of the simulated water-table contours changed only slightly at the regional scale for the nine scenarios, with the largest shifts in contours within the HPWMA resulting from drawdown near the HPWMA and water-table mounding near the Barnstable Water Pollution Control Facility (WPCF). Drawdowns relative to the 2015 reference pumping condition were expected because of the simulated 3-34-percent increases in total withdrawals and the addition of two wells in the HPWMA. The increased withdrawals were accompanied by an increase in wastewater return flow to the Barnstable WPCF that caused mounding of the water table at the WPCF. The simulation results illustrate that overall changes in water levels are affected by both changes in rates and locations of water-supply withdrawals and recharge of wastewater return flow.

The use of the model to simulate the response of watertable and pond-level changes to changes in pumping for water supply and associated wastewater recharge is subject to several assumptions and limitations:

- The scenarios include changes only to withdrawals and recharge of wastewater return flow for the HWS and its service area. Changes to rates and locations of withdrawals and return flow for other nearby water-supply systems also could affect water levels in and near the HPWMA, but these changes were not considered in this analysis.

- The groundwater-flow model simulates only steadystate conditions and is based on the assumption that pumping and wastewater return-flow rates are time-invariant at their long-term average conditions. Because the concern addressed in this study is a long-term shift in average pond levels that could permanently alter the pond-shore habitat, steady-state simulations were deemed sufficient for this analysis.

- The model assumes that the hydraulic connection between the ponds and the water-table aquifer is good and that pond levels adjust to follow changes in the water-table level. The presence of fine-grained sediments on the pond bottoms, especially at the smaller ponds, could cause pond levels to be higher than the surrounding water table during periods of declining water levels.

- Hydraulic characteristics of the aquifer at a local scale, such as the reported presence of a layer of fine-grained sediments near the HPWMA and finegrained sediments on parts of the pond bottoms, are not represented explicitly in the regional groundwaterflow model. The observed higher-than-simulated water levels near the eastern part of the HPWMA could be related to the fine-grained layers or to other unidentified hydrologic stresses.
The regional groundwater-flow model was not constructed specifically to represent the ponds in the HPWMA and the effects of nearby withdrawals. Data about the hydrogeologic characteristics of the aquifer and hydraulic heads and streamflows used to construct and calibrate the model were sparse for the area near the HPWMA. A model with a finer grid spacing might enable explicit representation of the smaller ponds and better characterization of hydraulic properties, such as the hydraulic conductivity of pond-bottom sediments, that affect the hydraulic connection between the ponds and the aquifer. Further examination of the effects of nearby pumping activities on pond levels, the hydraulic connection between the ponds and aquifer, transient hydrologic flow and storage, and local variations in hydraulic properties was beyond the scope of this investigation. These effects could be examined during the hydrologic testing and analysis that would likely be part of future efforts to develop water-supply sources in the area.

\section{References Cited}

Cape Cod Commission, 2008, Barnstable ponds-Current status, available data, and recommendations for future activities: Final report, prepared for the Town of Barnstable Conservation Division, July 2008, 77 p., accessed November 19, 2019, at https://tobweb.town.barnstable.ma.us/ departments/Conservation/Wequaquet/WeqInBarnstablePonds2008Report.pdf.

Harbaugh, A.W., 2005, MODFLOW-2005, The U.S. Geological Survey modular ground-water model-The groundwater flow process: U.S. Geological Survey Techniques and Methods, book 6, chap. A16, [variously paged]. [Also available at https://doi.org/10.3133/tm6A16.]

IEP, Inc., 1990, Independence Park, Hyannis, MassachusettsSecond supplemental draft, environmental impact report, Chapter 3, Hydrogeology: Commonwealth of Massachusetts Executive Office of Environmental Affairs (EOEA) \#7193, October 1990, Volume 1-Text, p. 41-76.

LeBlanc, D.R., Guswa, J.H., Frimpter, M.H., and Londquist, C.J., 1986, Ground-water resources of Cape Cod, Massachusetts: U.S. Geological Survey Hydrologic Investigations Atlas HA-692, 4 pls., 1:24,000. [Also available at https://doi.org/10.3133/ha692.]

McCobb, T.D., and Walter, D.A., 2019, MODFLOW2005 groundwater-flow model used to simulate water-supply pumping scenarios near the Hyannis Ponds Wildlife Management Area, Barnstable, Massachusetts: U.S. Geological Survey data release, https://doi.org/10.5066/P9U5AKLC. 
McHorney, R., 1997, Hydrologic report, Hyannis Ponds project: Boston, Mass., The Nature Conservancy, September 1997, [71 p.]. [Also available at https:/www.townofsharon.net/conservation-commission/ files/hydrologic-report-hyannis-ponds-project.]

McHorney, R., and Neill, C., 2007, Alteration of water levels in a Massachusetts coastal plain pond subject to municipal ground-water withdrawals: Wetlands, v. 27, no. 2, p. 366-380 [Also available at https://doi.org/10.1672/02775212(2007)27[366:AOWLIA]2.0.CO;2.]

Merritt, M.L., and Konikow, L.F., 2000, Documentation of a computer program to simulate lake-aquifer interaction using the MODFLOW ground-water flow model and the MOC3D solute-transport model: U.S. Geological Survey WaterResources Investigations Report 2000-4167, 146 p.

Oldale, R.N., 1992, Cape Cod and the Islands-The geologic story: East Orleans, Mass., Parnassus Imprints, 208 p.

Walter, D.A., McCobb, T.D., Masterson, J.P., and Fienen, M.N., 2016, Potential effects of sea-level rise on the depth to saturated sediments of the Sagamore and Monomoy flow lenses on Cape Cod, Massachusetts (ver. 1.1, October 2016): U.S. Geological Survey Scientific Investigations Report 2016-5058, 55 p., accessed October 25, 2016, at https://dx.doi.org/10.3133/sir20165058.
Walter, D.A., McCobb, T.D., and Fienen, M.N., 2019, Use of a numerical model to simulate the hydrologic system and transport of contaminants near Joint Base Cape Cod, western Cape Cod, Massachusetts: U.S. Geological Survey Scientific Investigations Report 2018-5139, 98 p., accessed April 18, 2019, at https://doi.org/10.3133/sir20185139.

Walter, D.A., and Whealan, A.T., 2005, Simulated water sources and effects of pumping on surface and ground water, Sagamore and Monomoy flow lenses, Cape Cod, Massachusetts: U.S. Geological Survey Scientific Investigations Report 2004-5181, 85 p. [Also available at https://doi.org/10.3133/sir20045181.]

Westenbroek, S.M., Kelson, V.A., Dripps, W.R., Hunt, R.J., and Bradbury, K.R., 2010, SWB-A modified Thornthwaite-Mather soil-water-balance code for estimating groundwater recharge: U.S. Geological Survey Techniques and Methods, book 6, chap. A31, 59 p., software. [Also available at https://doi.org/10.3133/tm6A31.] 


\section{Appendix 1. Modifications to the Groundwater-Flow Model and Results of the Model Recalibration}

\section{Introduction}

The three-dimensional, steady-state groundwater-flow model used to simulate water-table and pond-level changes for proposed water-supply withdrawals in the Hyannis Ponds Wildlife Management Area is a modified and recalibrated version of the model used to simulate the potential effects of sealevel rise on groundwater levels of the Sagamore and Monomoy flow lenses (fig. 1.1) of the Cape Cod aquifer (Walter and others, 2016). This appendix describes the modifications made to the original model and results of recalibration of the modified model to 2010 hydrologic conditions. The modified model and its associated model archive (McCobb and Walter, 2019) supersede the original model described in Walter and others (2016).

\section{Description of Regional Groundwater-Flow Model}

The original regional groundwater-flow model is a threedimensional steady-state groundwater-flow model of the Sagamore and Monomoy flow lenses (fig. 1.1) developed by using the finite-difference modeling program MODFLOW-2005 (Harbaugh, 2005). Detailed descriptions of the model construction, input and calibration data, and calibration approach and results are given in Walter and others (2016).

The model grid extends from the Cape Cod Canal to Town Cove and consists of 346 rows, 568 columns, and 25 layers with a uniform horizontal discretization of 400 feet ( $\mathrm{ft}$ ). The top of the model is simulated as unconfined, and the bottom of the model is simulated as the bedrock surface or the freshwater/saltwater interface. Surface-water features, including streams, wetlands, and coastal water bodies, are simulated by using various types of boundary conditions. Ponds are simulated as zones of essentially infinite hydraulic conductivity. Hydraulic stresses include pumping for water supply from about 153 wells and recharge of wastewater return flow at wastewater treatment facilities and septic systems (table 1.1). Natural recharge from precipitation is based on climate data from 1949 to 2012 and is applied uniformly on the modeled area at a rate of about 28.7 inches per year (in/yr).

The original model was calibrated to observations of water levels (heads) and streamflows for the period 19952000. Model parameters - recharge, boundary leakances, and hydraulic conductivity - were adjusted by using the PEST inverse calibration method (Doherty, 2010) to obtain a best fit of the simulated heads and streamflows to their simulated equivalents. Absolute mean residuals between observed and simulated water levels and streamflows for highly weighted observations considered representative of long-term average conditions were $0.30 \mathrm{ft}$ and 0.29 cubic foot per second $\left(\mathrm{ft}^{3} / \mathrm{s}\right)$, respectively.

\section{Modifications to Regional Groundwater-Flow Model}

Two modifications - the addition of spatially variable natural recharge from precipitation, and a revised representation of wastewater return-flow recharge to septic systems in the town of Barnstable - were made to the original regional groundwater-flow model (Walter and others, 2016) for this study. The modified model was recalibrated to the same observations of heads and streamflows as those used by Walter and others (2016). The modifications and results of the recalibration are described in this section.

\section{Description of Modifications}

Walter and others (2016) used the Soil-Water-Balance (SWB) computer code (Westenbroek and others, 2010) and climate, soils, and other data to estimate the spatial distribution of natural recharge on Cape Cod from 1949 to 2012. Figure 11 of Walter and others (2016) is a map of the model extent showing the spatially variable average recharge rates. In the data input files of the original model, however, the recharge rates from the SWB model were not used; the calibrated mean recharge rate was applied uniformly over the model extent. The modified model used for this study implemented the spatially variable recharge from the SWB model as described in Walter and others (2016). The spatially variable rates were scaled in the calibrated model by a mean recharge parameter that was determined during the calibration process.

In the data input files of the original model, wastewater return flow recharged through septic systems was estimated from total withdrawals for the five water-supply systems serving Barnstable's villages scaled at a parcel scale based on metered water use. The model input files were modified for this study to allow estimation of wastewater return flow recharged through septic systems separately for each village based on the pumping for the water system serving the village. This modification did not change the distribution of wastewater return flow to septic systems for the calibration period (2010) but provided flexibility to make village-by-village adjustments when simulating proposed changes to pumping scenarios in the town. 


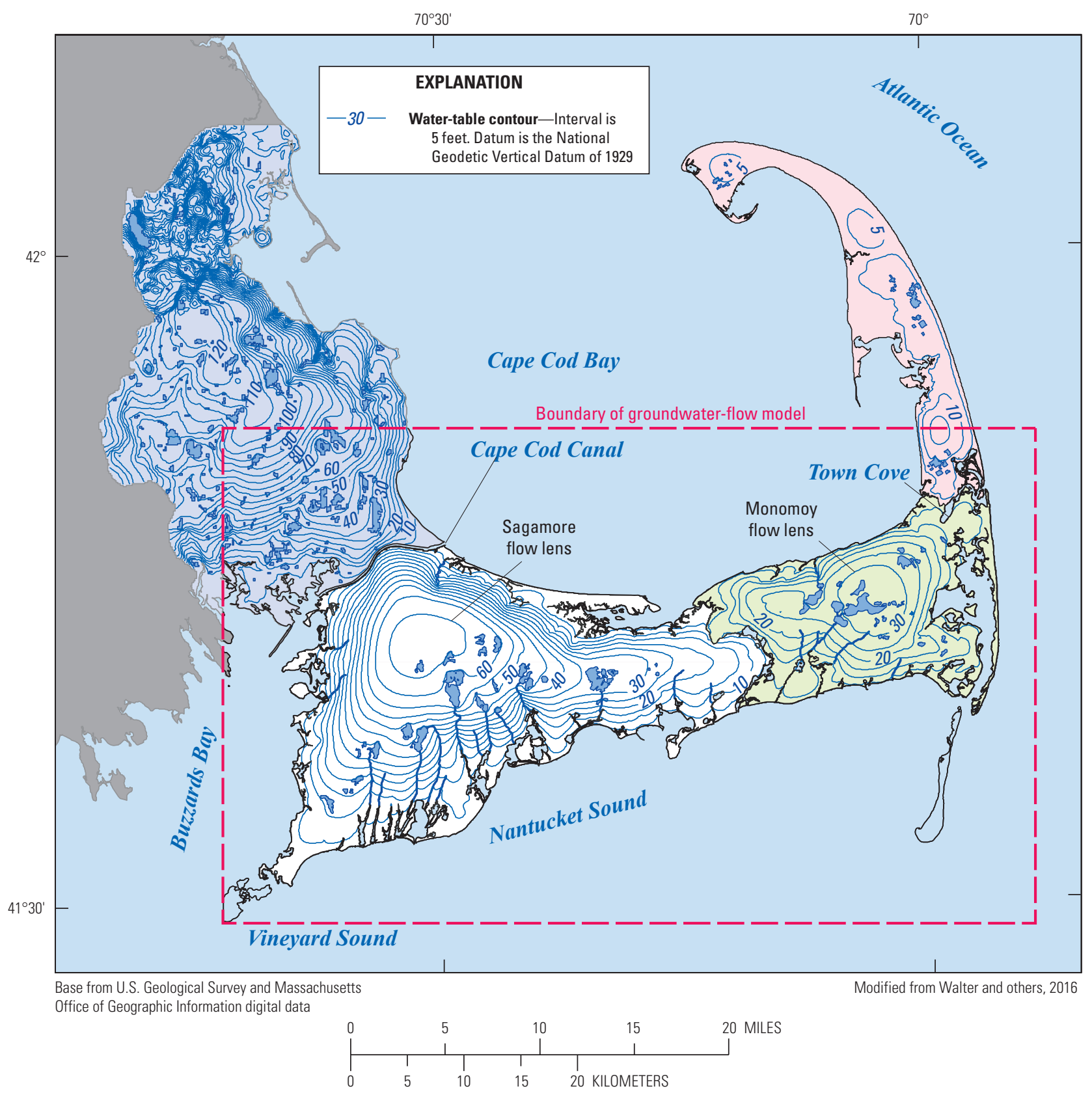

Figure 1.1. Extent of model grid of the regional groundwater-flow model (adapted from Walter and others, 2016, fig. 12). 


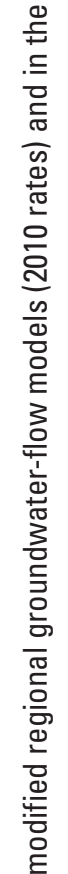

离

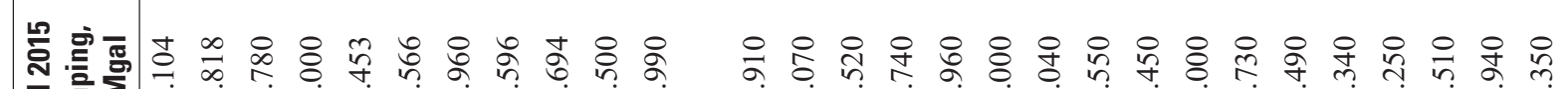

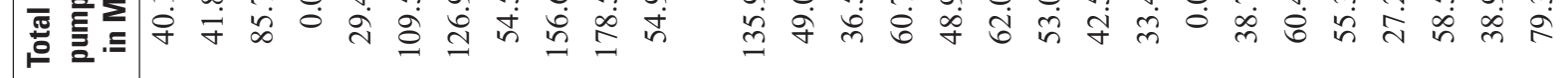

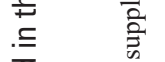

$$
\text { 西 }
$$

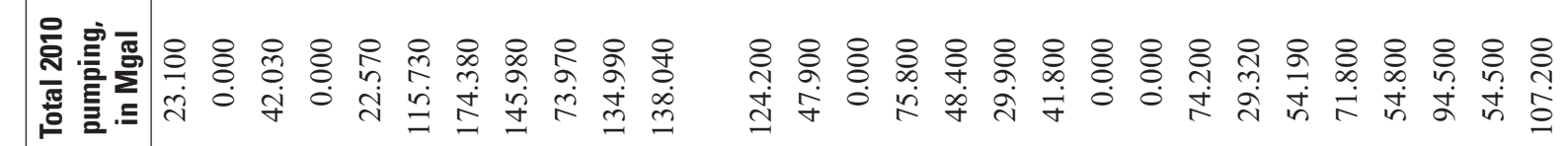

ప

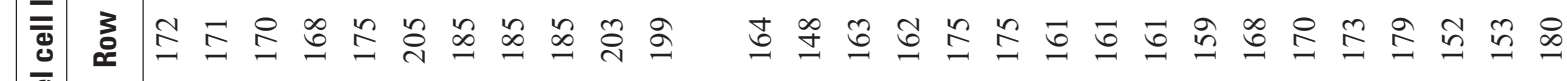

)

ฏ

mandmeta

要

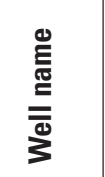

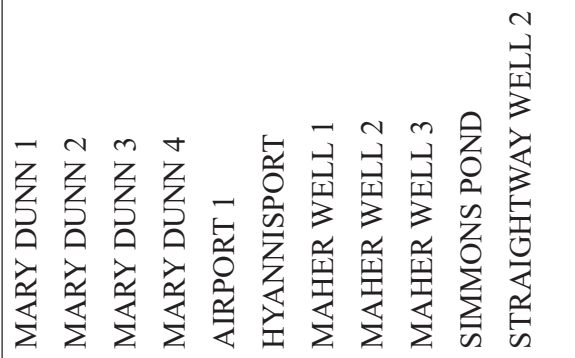

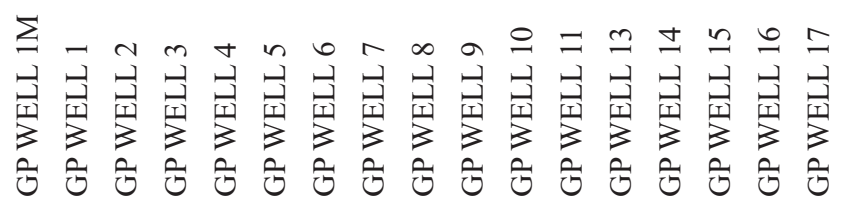

?

흔

$$
\stackrel{0}{\leftrightarrows}
$$

.

壱

is $\frac{1}{\mathrm{c}}$

必完

층 은

윽 둥

ป d

उ ब

는 원

$\frac{\pi}{\pi}$

츙 ฏ

흘 $\stackrel{0}{\leftrightarrows}$

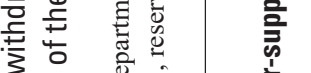

$\sum_{i=1} \sum_{i=1} \sum_{i=1} \sum_{i=1} \sum_{i=1} \sum_{i=1} \sum_{i=1}$

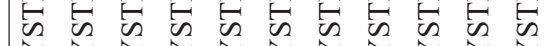
公公公公公公公公公公公

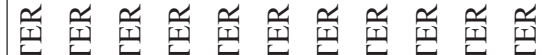

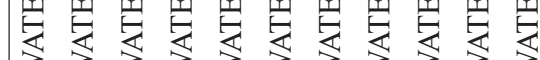

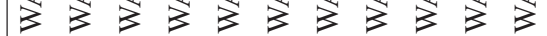

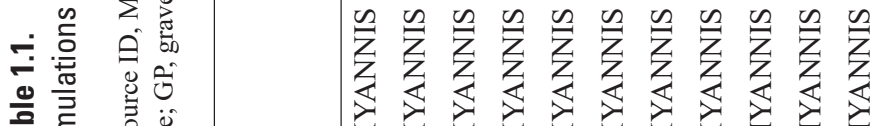

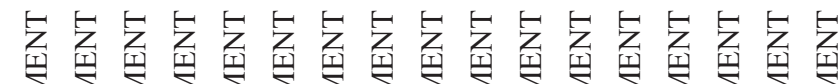
$\sum_{i=1} \sum_{i=1} \sum_{i=1} \sum_{i} \sum_{i} \sum_{i} \sum_{i=1} \sum_{i} \sum_{i=1} \sum_{i=1}^{Z}$

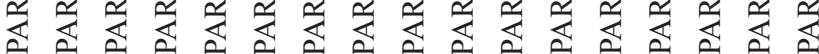
त्ञ

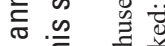

西 후 훈

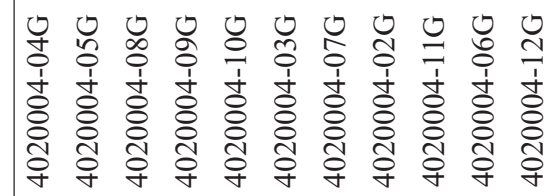

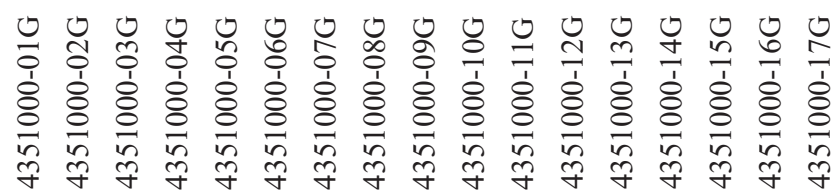

. $\sum^{\pi}$

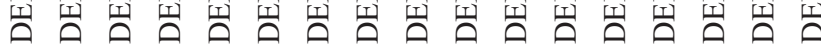

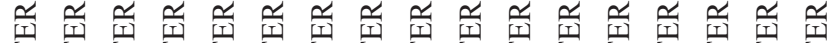

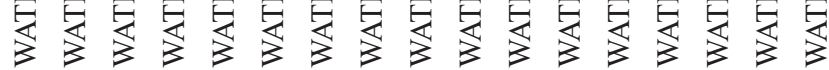

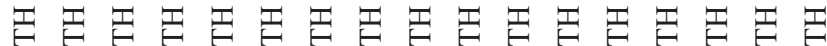
$\sum \sum \sum \sum \sum \sum \sum \sum \sum \sum \sum \sum \sum \sum \sum \sum$

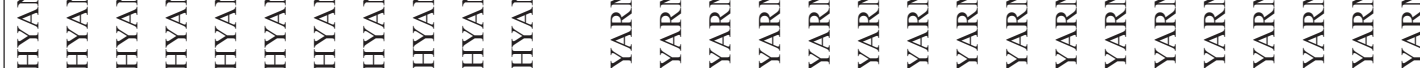




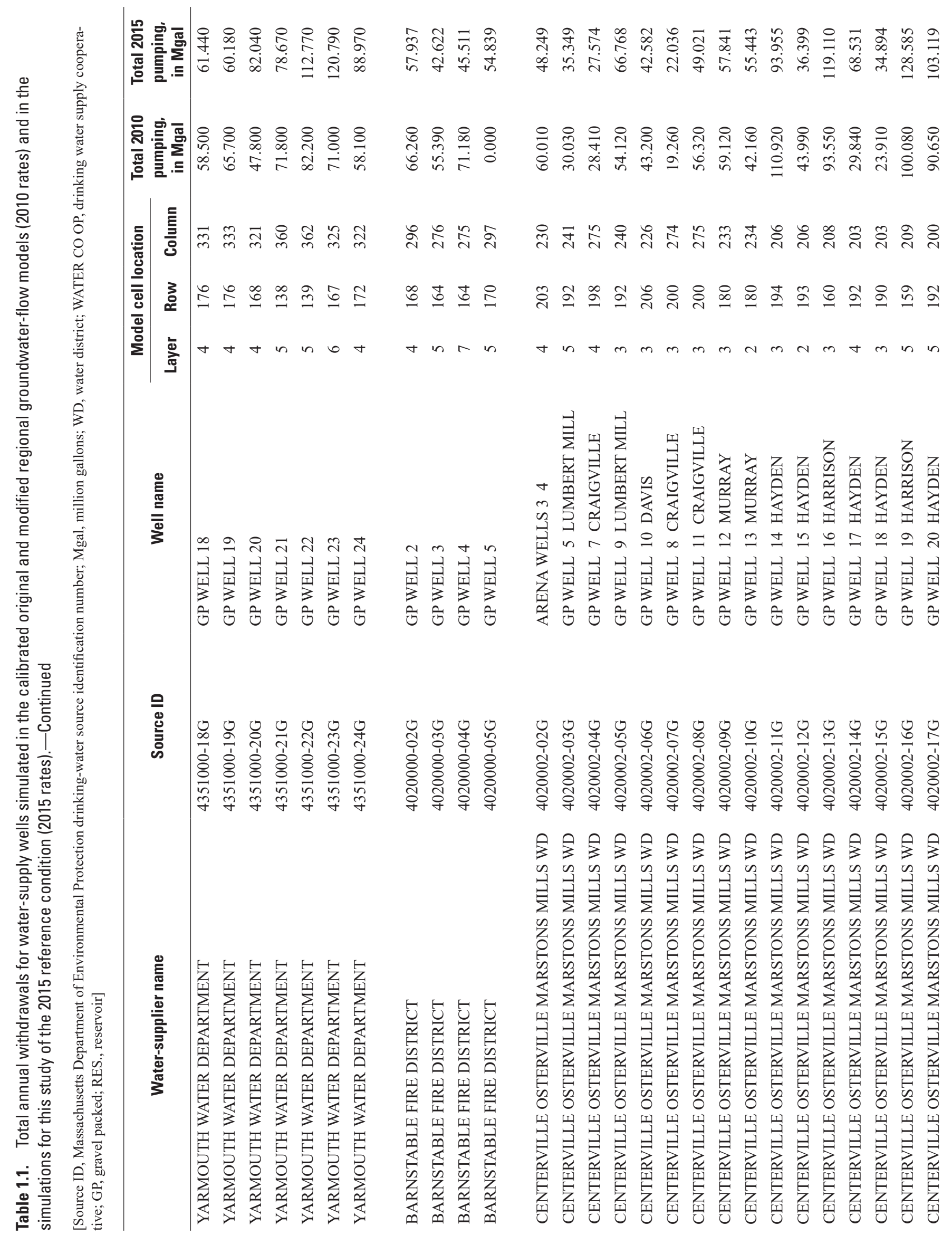




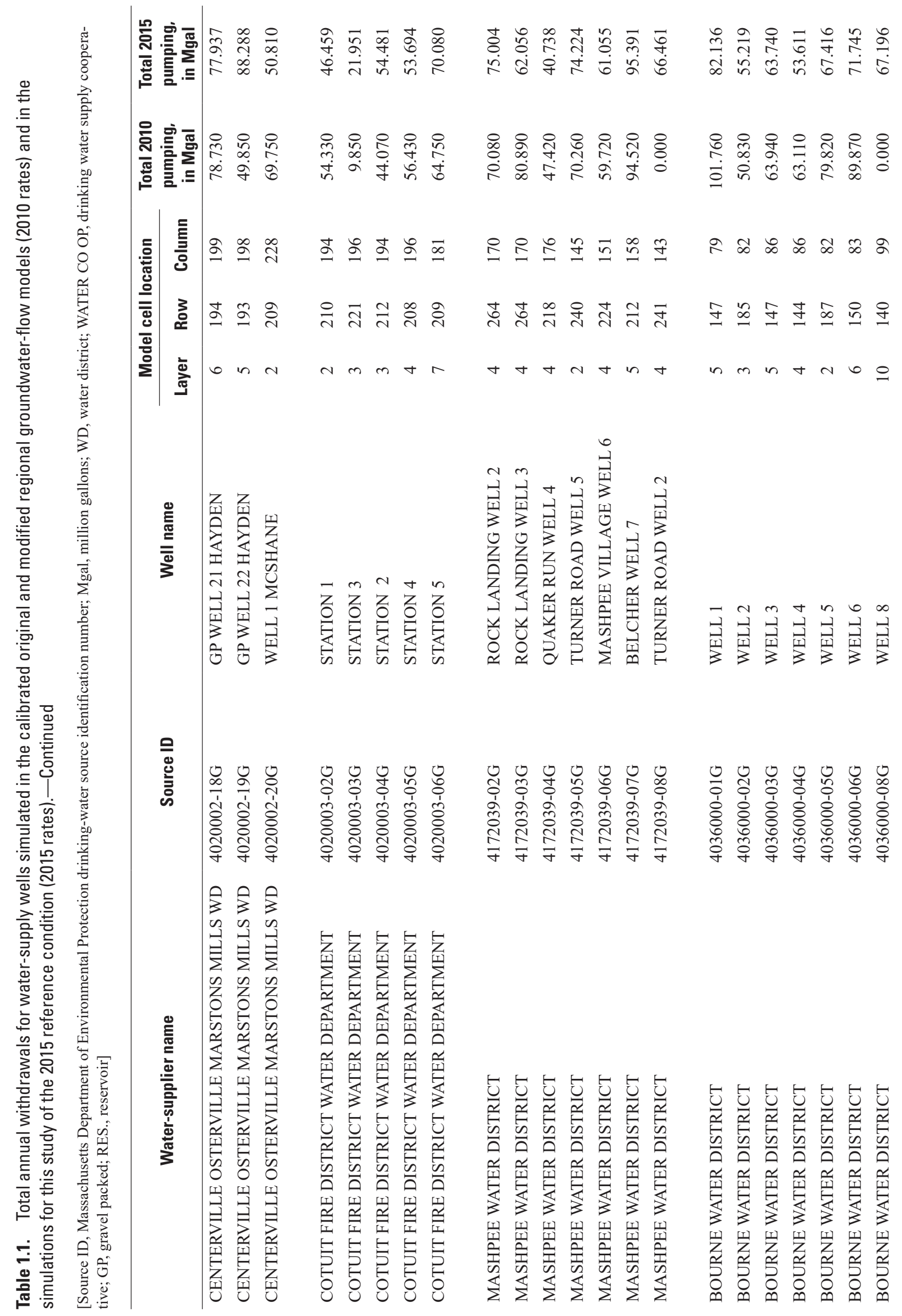




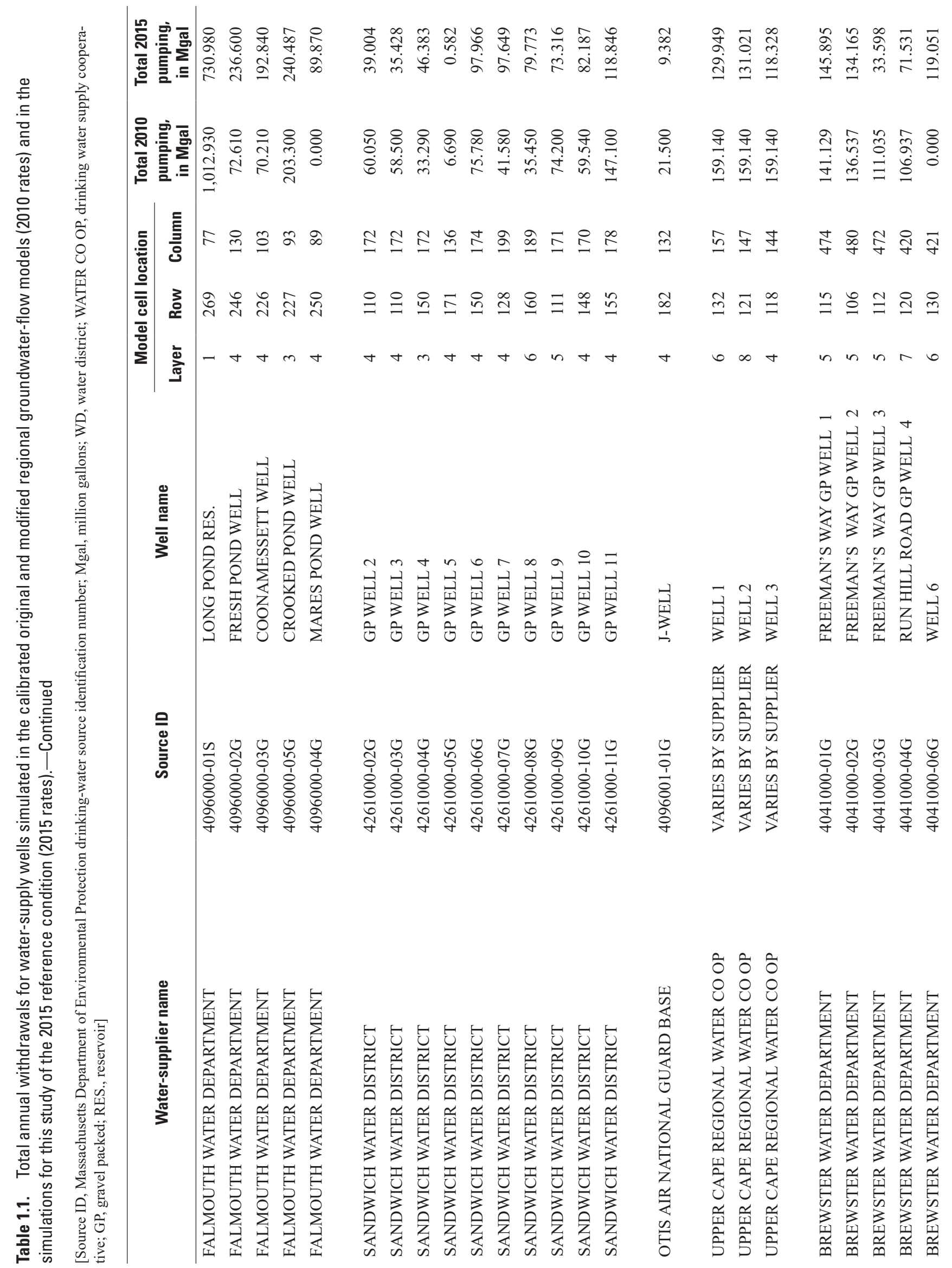




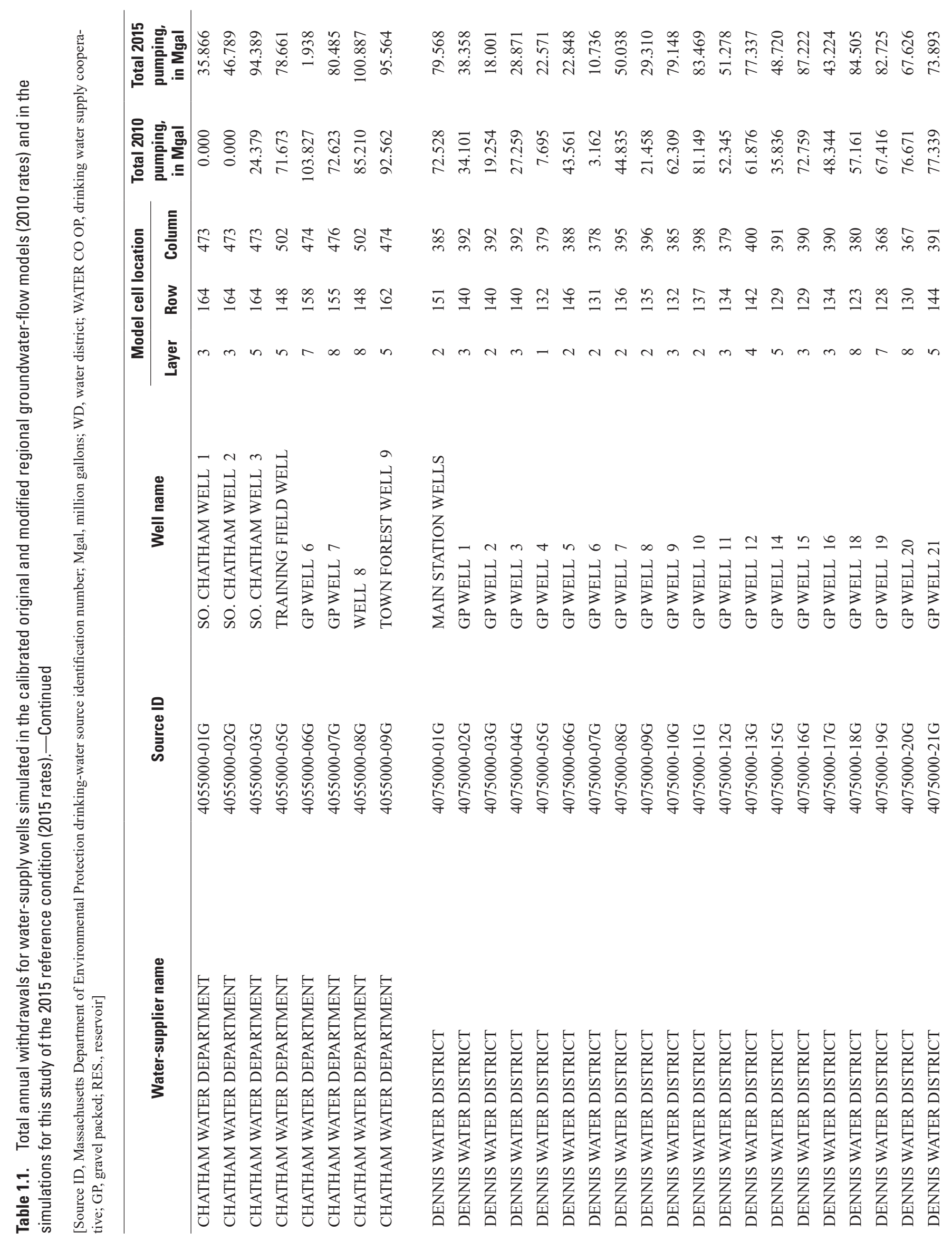




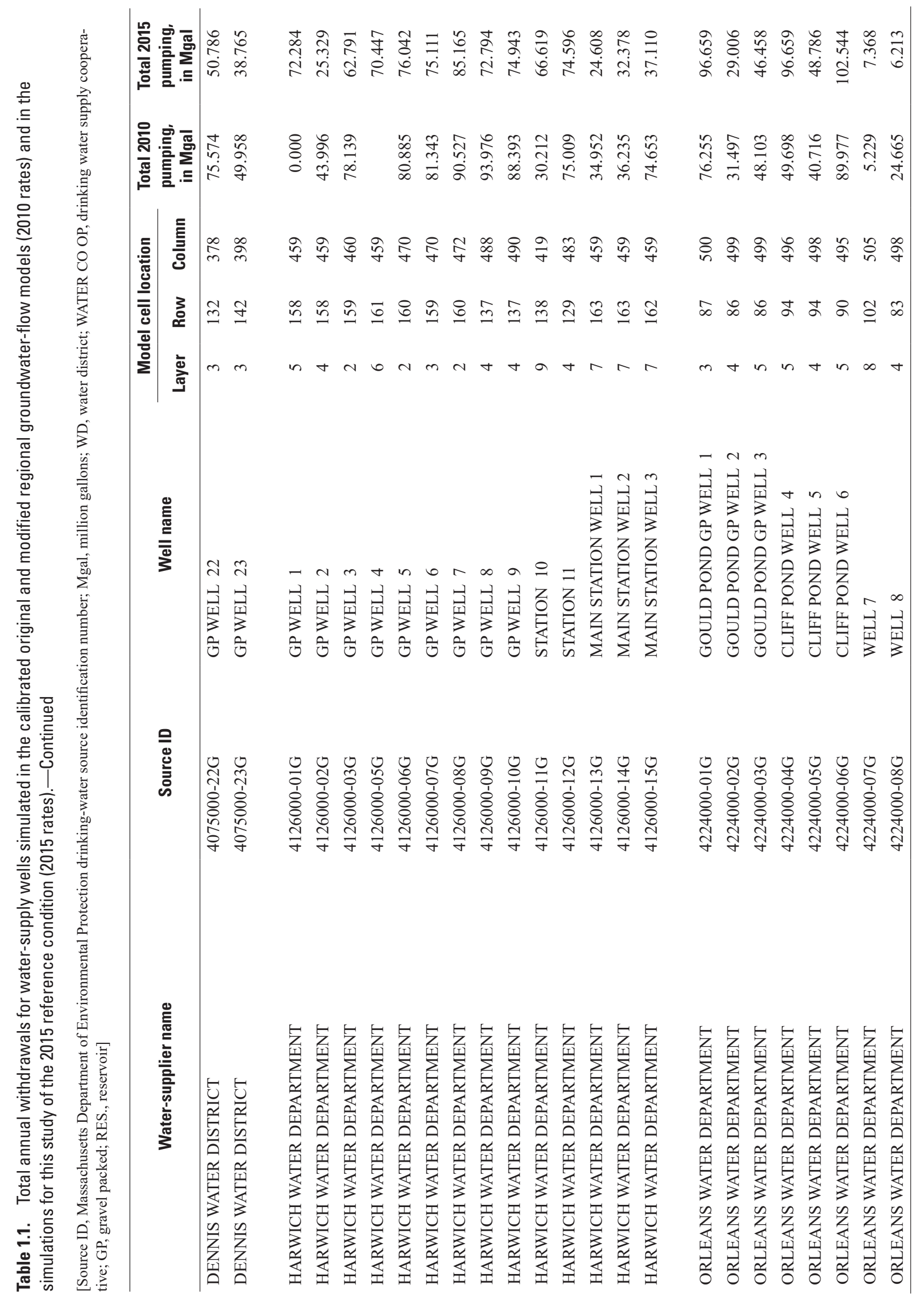




\section{Recalibration of Modified Model}

The PEST (Doherty, 2010) inverse calibration method described in Walter and others (2016) was used to recalibrate the modified regional groundwater-flow model. The original and modified models are identical except for the modifications described in the previous section. The two models use the same 2010 withdrawal rates, head and streamflow observations, and boundary specifications reported in Walter and others (2016).

Recalibration of the modified model by using the same hydraulic-conductivity constraints as model variant number 1 described in Walter and others (2016) resulted in final distributions of horizontal and vertical hydraulic conductivity that provided a best fit to observed heads and streamflow that was comparable to the best fit in the original model. The mean horizontal hydraulic conductivity for model layers in the three adjustable vertical-parameter groups (groups 1, 2, and 3 with increasing depth) changed from the original model by $-8.4,-6.9$, and 18 percent, respectively. The calibrated values for boundary leakances for estuarine sediments and streambeds were 0.09 and $0.99 \mathrm{ft} / \mathrm{d}$, respectively, also similar to the calibrated parameters of the original model. The calibration yielded a mean recharge rate of $27.5 \mathrm{in} / \mathrm{yr}$. This rate was applied to a multiplier array to simulate spatially variable recharge as determined from the SWB model. Distribution of the multiplier values is described in Walter and others (2016).
The inverse-calibration simulation that resulted in the best fit of the observed heads and streamflows to their simulated equivalents yielded absolute mean residuals of $1.12 \mathrm{ft}$ and $0.90 \mathrm{ft}^{3} / \mathrm{s}$ for highly weighted head and streamflow observations, respectively. Observed and simulated water levels generally were in close agreement, with no discernable trends in residual distribution with respect to simulated values, indicating little spatial bias in the model (figs. $1.2 \mathrm{~A}$ and $1.2 B$ ). Simulated streamflows at 15 locations where measurements were considered representative of long-term average conditions were also in close agreement (fig. 1.3). The residuals for the streamflows at sites with continuous records - Quashnet River \#1 and Herring River \#1-were 0.07 and $0.59 \mathrm{ft}^{3} / \mathrm{s}$, respectively.

The original and modified models use the same withdrawal and return-flow rates and calibration heads and streamflow. Therefore, the total flux through the groundwater system is about 4 percent smaller in the modified model than in the original model. The lower recharge in the modified model (mean of $27.5 \mathrm{in} / \mathrm{yr}$ ) than in the original model (mean of $28.7 \mathrm{in} / \mathrm{yr}$ ) results in slightly lower transmissivities and decreases in discharge to coastal waters in the modified model than in the original model. The modified model used for this study is considered to be more representative of the groundwater-flow system and, therefore, supersedes the original model described in Walter and others (2016). 

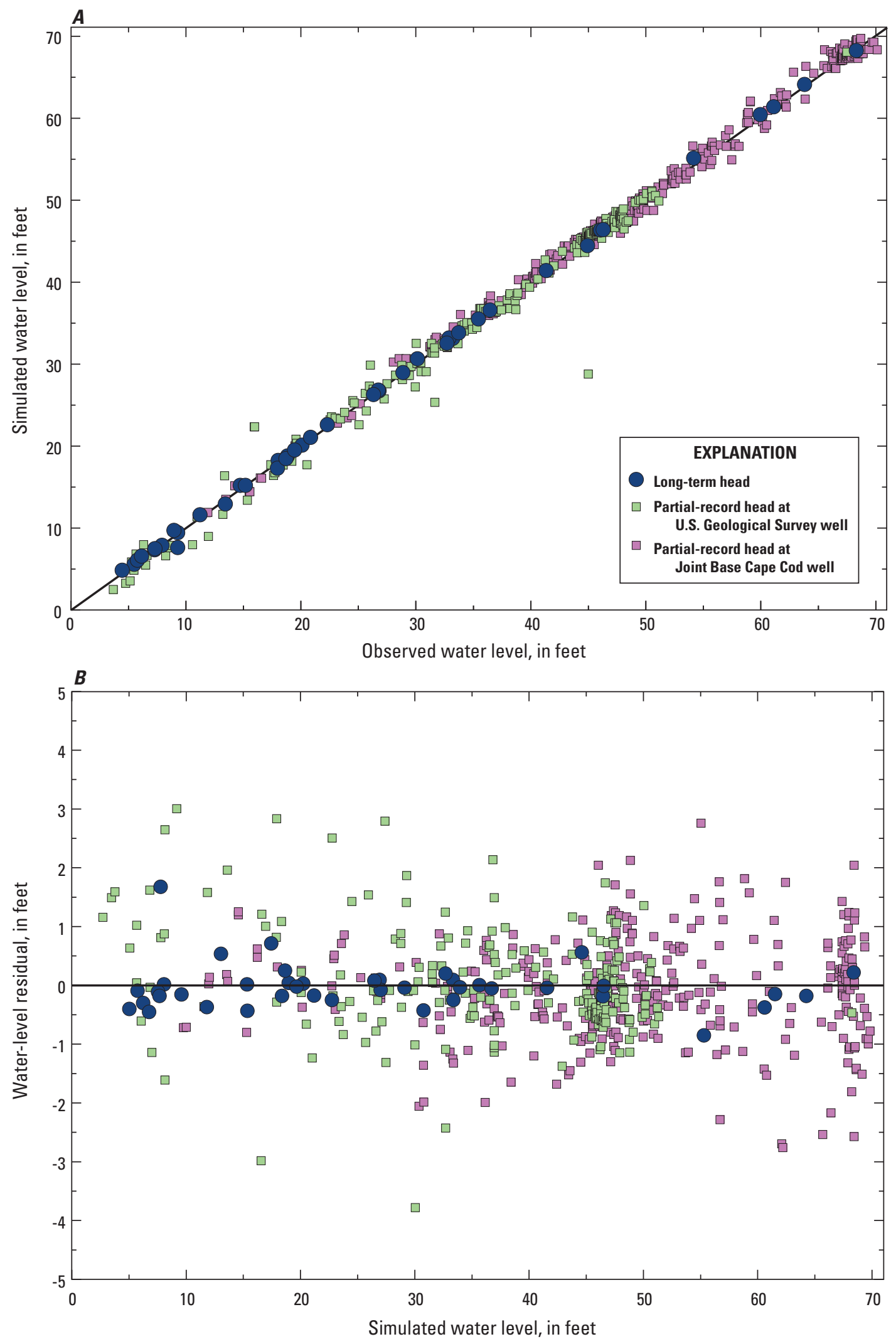

Figure 1.2. $A$, Observed water levels and simulated equivalents and $B$, distribution of head residuals as a function of simulated equivalents for the recalibrated regional groundwater-flow model. Equivalent to figure 19 in the documentation of the original model (Walter and others, 2016). 


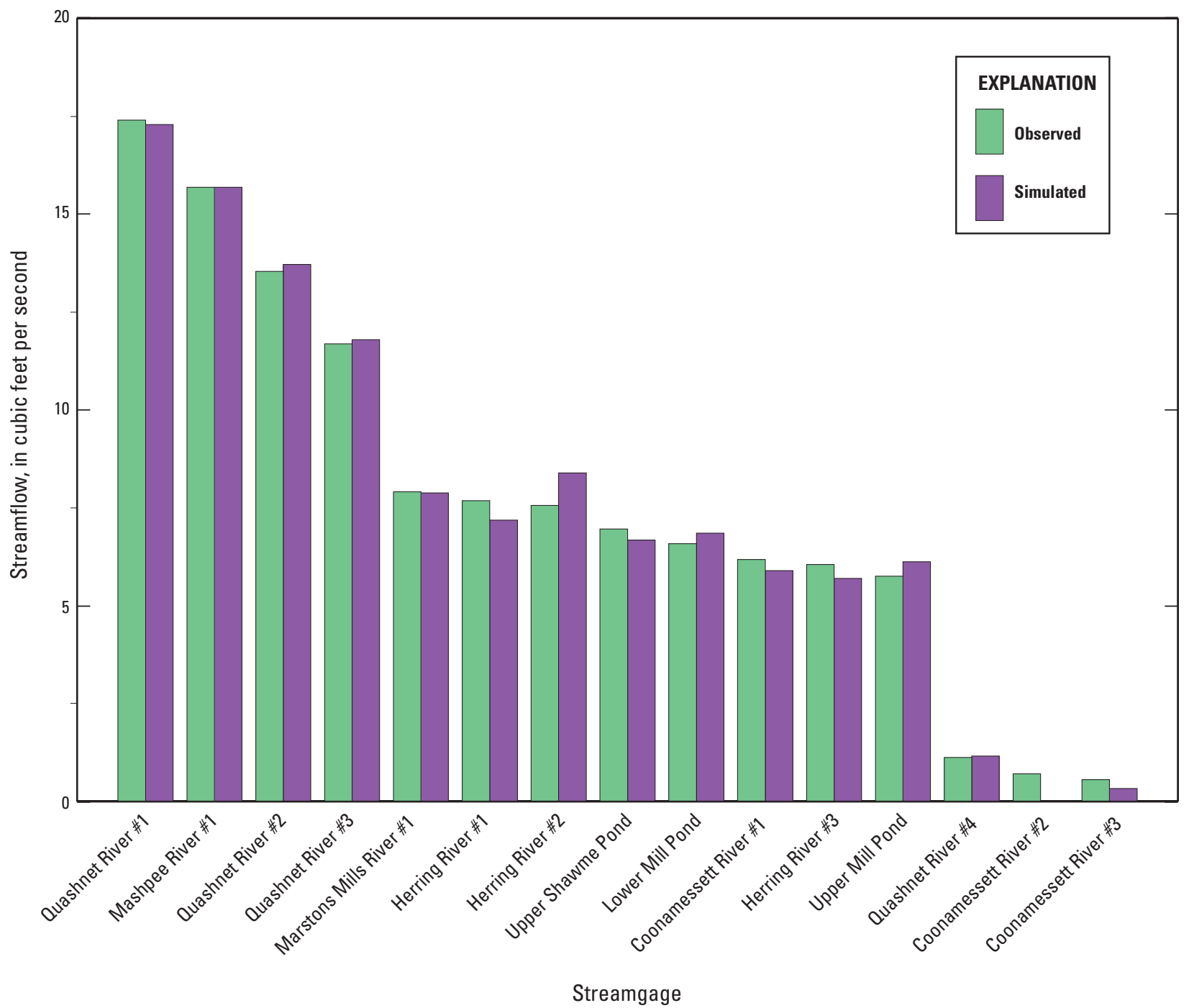

Figure 1.3. Observed and simulated streamflows for highly weighted observations for the recalibrated regional groundwater-flow model. Equivalent to figure 20 in the documentation of the original model (Walter and others, 2016). 


\section{References Cited}

Doherty, J., 2010, PEST-Model-independent parameter estimation-User manual (5th ed., revised): Brisbane, Australia, Watermark Numerical Computing, 336 p., accessed May 12, 2012, at http:/www.pesthomepage.org/Downloads.php.

Harbaugh, A.W., 2005, MODFLOW-2005, The U.S. Geological Survey modular ground-water model-The groundwater flow process: U.S. Geological Survey Techniques and Methods, book 6, chap. A16, [variously paged]. [Also available at https://doi.org/10.3133/tm6A16.]

McCobb, T.D., and Walter, D.A., 2019, MODFLOW2005 groundwater-flow model used to simulate water-supply pumping scenarios near the Hyannis Ponds Wildlife Management Area, Barnstable, Massachusetts: U.S. Geological Survey data release, https://doi.org/10.5066/P9U5AKLC.
Walter, D.A., McCobb, T.D., Masterson, J.P., and Fienen, M.N., 2016, Potential effects of sea-level rise on the depth to saturated sediments of the Sagamore and Monomoy flow lenses on Cape Cod, Massachusetts: U.S. Geological Survey Scientific Investigations Report 2016-5058 (ver. 1.1, October 2016), 55 p., accessed October 25, 2016, at https://dx.doi.org/10.3133/sir20165058.

Westenbroek, S.M., Kelson, V.A., Dripps, W.R., Hunt, R.J., and Bradbury, K.R., 2010, SWB-A modified Thornthwaite-Mather soil-water-balance code for estimating groundwater recharge: U.S. Geological Survey Techniques and Methods, book 6, chap. A31, 59 p., software. [Also available at https://doi.org/10.3133/tm6A31.] 
For more information about this report, contact: Director, New England Water Science Center U.S. Geological Survey

331 Commerce Way, Suite 2

Pembroke, NH 03275

dc_nweng@usgs.gov or visit our website at https://www.usgs.gov/centers/new-englandwater

Publishing support provided by the Pembroke Publishing Service Center 


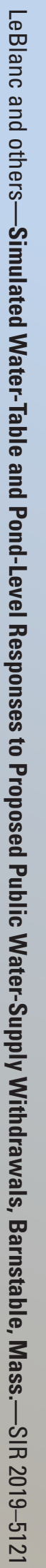

